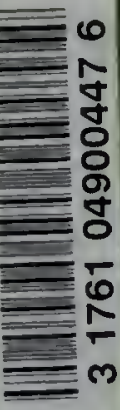


Digitized by the Internet Archive in 2008 with funding from Microsoft Corporation 



$$
\text { . }
$$


BRITISH MUSEUM (NATURAL HISTORY). Lept. of Ento, ol

\section{STUDIES ON ACARI.}

\section{No. 1. \\ The Genus DEMODEX, OWEN.}

(WITH THIRTEEN PLATES AND FOUI: TEXT-FIGURES.)

$\mathrm{BY}$

STANLEY HIRST

(Assistant in the Department of Zoology).

L O N D ON :

RRINTED BY ORDER OF TUE TRUSTFES OF TIIE BRITISII MUSEUM. 1919.

[All rights reserved.] 


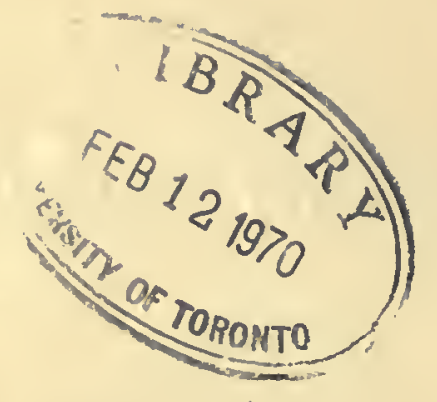

PRINTED BY TAYLOR AND FRANCIS, RED LION COURT, FLEET STREET.

$$
\begin{aligned}
& \text { QL } \\
& 458 \\
& \text { AD } 375
\end{aligned}
$$




\section{PREF A CE.}

Trre present work constitutes the first part of the studies on parasitic Acari in which the author, Mr. S. Hirst, has been engaged for some time. The representatives of the genus Demodex are skin-parasites of microscopic size. Although certain species give rise to troublesome affections of the skin, others are not definitely known to be harmful. D. folliculorum, a parasite which is so common that it has been stated to occur in "practically every human being," is regarded as harmless by the majority of the authorities who have studied it, although it las been accused by other students of the group of being instrumental in carrying certain grave diseases. Since these animals live embedded in the skin of their host, their detection is not easy without practice; but the success of the author in finding them in Mammals in which they had not previously been recorded, or had been supposed to be rare, makes it appear probable that many specics remain to be discovered. An accurate knowledge of this group is highly desirable, as there are many instances of parasites at first belicved to be harmless which have been found, with increased knowledge, to be extremely injurious to the health of their hosts, either by their direct effects or by acting as the carriers of disease.

The thanks of the Trustees are duc to Messrs. 'linylor and Francis for permission to reproduce figs. $39,41,42 a, 46,47$; to the Belgian Government, Lt.-Col. A. W. Alcock, F.R.S., Lient. Leslie Linzell, and M. R. van Saceghem for specimens; and to Mr. M. A. C. Hinton for assistance in connexion with the Mammalian hosts.

Britisit Musiem (Natural IIistony),

SIDNEY F. HARMLR, Loxnox, S.IV.7.

Keeper of Zoology. April 1, 1919. 



\section{CONTENTS.}

Preface

Frequexcy of Occurrence and Eftects of the Parastism of Deuodex on TIIE Host

Demodex and Man

Follicular or Demodectic Mange of the Dog and its Treatment . . . 3

Demodectic Mange of the Cat . . . . . . . . . . . . . . 6

\begin{tabular}{|c|c|c|c|c|c|c|c|c|c|c|c|c|c|c|}
\hline ", & $"$ & the Horse & • & . & & & & & & & & & & . \\
\hline " & $"$ & Cattle & . & - & & & & & & & & & & . \\
\hline & $"$ & the Pig. & • & - & & & & & & $\cdot$ & & • & 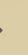 & - \\
\hline & , & the Gont & . & . & & & & & & • & & . & • & . \\
\hline
\end{tabular}

Brief Historical Account of the Group . . . . . . . . . . . . . 9

Origix and Affixities of tue Demodicide . . . . . . . . . . . . . 10

HADITS . . . . . . . . . . . . . . . . . . . 12

Externat MorpmologY • . . . . . . . . . . . . . . . . 12

Capitulum . . . . . . . . . . . . . . . . . . 12

Legs . . . . . . . . . . . . . . . . . . 15

Respiratory System . . . . . . . . . . . . . . 15

Sexual Openings and Penis . . . . . . . . . . . 16

TAYONOMY . . . . . . . . . . . . . . . . . . 17

Sistematic List uf tire Species and Varieties of tire Gexus Demodex, witu thiezr Hosts and known Distribution . . . . . . . . . . . . . 18

Descriptions of mie Species and Tarieties . . . . . . . . . . . 19

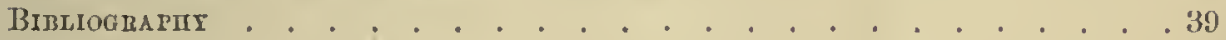

$\operatorname{Index}$. . . . . . . . . . . . . . . . . . . 40

Explanation of Plates . . . . . . . . . . . . . . . . . 42 



\section{S'TUUIES ON ACARI.}

\section{No. 1, The Genus Demodex.}

\section{FREQUENCY OF OCCURRENCE AND EFFECTS OF THE PARASITISM OF DEMODEX ON THE HOST.}

'T'ue species of Demodex usually seem quite innocuous, their presence apparently causing no inconvenience to their host. These parasites can be found in perfectly healthy animals-for instance, specimens have been collected by the author from mice, dormice, rabbits, a sheep, ficld mice, hedgehogs, etc., which showed no signs of skin-complaint. Very numerous specimens were found in the skin of a hibernating dormouse, the fur of which was nevertheless in perfect condition *.

Demodex and Man.-It has been pointed out by Gmeiner and many other specialists that $D$. folliculorum is very frequently met with in human beings but does not usually cause any disease. In the course of his researches Gmeiner examined over two hundred corpses besides living persons, and is of opinion that Demodex occurs in the skin of practically every human being. In America, Allen has published a casc of a skin-ernption resembling molluscum contagiosum in which specimcus of Demodex were very numerous, and Fordyce and Holder have recorded two instances of acne rosacea in which great numbers of the same parasite were present. De Amicis and others in Italy have considered Demodex to be associated with a pigmentary affection resembling tinea versicolor. Dubreuilh also has found these mites in a case of localised pigmentation of the skin, and Darier found numerous

* Acknowledgment is due to the following gentlemen for their kindness in presenting material utilised in this little memoir: The Belgian Government and M. R. ran Saceghem for specimens of $D$. bovis from the Belgian Congo; Lt.-Col. A. W. Alcock, F.R.S., for specimens of D. phylloidles (from the pig); and Lieut. Leslie Linzell for examples of $D$. equi and $D$. ratti, and for supplying me with much valuable information on the Demodectic mange of the horse. Mr. M. A. C. Hinton las also kindly helped me in collecting Nanmals and in ofler wiys.

T'lıanks are also due to Messrs. 'Tinylor \& Francis for kindly allowing the reproduction of Figs. 39, 41, 42u, 46 and 47 , which have appeared in the 'Anuals \& Nagazine of Natural History.' 
specimens in a case of lichen spinulosus. Demodex has also been thought to set up inflammation of the eyelids (Blepharitis), and it should be noted that these mites are frequently found in this position. Herman Lawrence has encountered numerous instances of an impetiginous eruption in human beings in Australia. "These cases have occurred in alults and resemble an impetigo contagiosa, but there would seem to be some difference from that affeetion. 'The lesions have a greater tendency to form rings, and the border of the skin is more definitely raised than in ordinary impetigo contagiosa. The pustulation is not so severe as in impetigo, nor do these cases respond so rapidly to the usual simple antiparasitic remedies as might be expected. Some patients have thought that the eruptions have followed upon shaving, but the lesions may be situated away from the hairy region, and be found on the forehead, neck, or on the nose. The feature common to all these cases is the extraordinary number of Demodex folliculorum which are demonstrable in the most simple scraping from the skin." According to Mr. Lawrence, the clinical picture has become so familiar to him that he is generally able to predict that great numbers of the Domodex will be found in a case. He found it best to treat lesions in which mites of the genus Demodex were present in great numbers by painting them with tincture of iodine after rubbing the part affected with a salicylic and boracic ether lotion. My brother, Captain L. F. Hirst, bacteriologist to a General Military Hospital at. Alexandria in Egypt, found numerous specimens of Demodex in a scalp disease simulating alopecia areata. According to Borrel and others, Demodex is especially abundant in cancerous lesions, and he also suggests that the germs of leprosy may perhaps be carried from a person suffering from this disease to a healthy individual.

Domenico Majocchi has written several important and well illustrated papers on Demodcx. He draws attention to the presence of mites of this genus in the moibomian and ciliary glands of man and several other mammals. In another paper this author points out the occurrence of $\mathrm{D}$. folliculorum in certain rare skin-diseases, including a maculose skin complaint, also seborrhœa, blepharitis, etc. The possibility of the transmission of the bacillus of leprosy by Icmodex is also discussed by Majocchi. Lefebre states, however, that the idea that Demodex is an active propagator of leprosy must be abandoned. It should be borne in mind that parasites of all kinds are more numerous in sickly persons and animals, but this does not necessarily imply that they are the cause of the discase from which they are suffering. 
Gmeiner examined numerous cases of skin-disease (Alopecia, Carcinoma, Eczema, Furunculosis, Herpes, Impetign, Lichen, Lupus, Pityriasis, etc.), and could not find specimens of Demodex in the majority of cases; when present the mites were not more numerous than in the sound parts of the skin.

Follicular mange of the Dog*.-Perhaps the most serious disease in which Demoelex is found is the so-called Follicular or Red Mange of the dog. In typical cases of this complaint the mites are found in enormous numbers, but Gmeiner and also Mettam have shown that D. canis is not the actual cause of follicular mange, which is due to a bacterium (Staphylococcus pyogenes albus or some allied form). The mite plays an important part in the disease, however, by preparing the ground for the invasion of the bacterium by dilating the follicles and sweat-ylands, and possibly also carries and introduces the germ. Whilst the Acari remain in the follicles or sweat-glands some of the bacteria may penetrate more deeply and be conveyed from one point to another ly the blood-stream. The clinical symptoms of follicular mange vary very greatly: sometimes it assumes a pustular form characterised by nuncrous pustules accompanied by various crusts, etc.; in other cases it is a squamous affection with numerous epidermal pellicles, and sometimes the irritation is not very great in this variety. There is also a furm of the disease with circular patches accompanied by large pustules. In a typical case there are small hairless patches, together with reddish pimples and pustules, skin hot and thickened in the affected places, etc.

'The first symptoms of demodectic mange consist of slightly reddish hairless patches or spots with pustules, at the elbows, around the eyes, etc. These hairless patches gradually spread, becoming redder and appearing also on the inner surface of the feet and on the cheeks. The eyelids become swollen and inverted and have a purulent margin. The skin of the sides of the cheeks is thickened, devoid of hair, and covered with various papules and pustules in varying stages of irritation. Pruritus is still intermittent at this stage but more marked. The malady at last becomes generalised and occupies most of the surface of the body. 'lihere are numerous pustules, and in places they become confluent; crusts due to the morbid secretions also make their appearance. In some places the skin is moist and chapped, and there is a yellowish matter in the folds of the skin. A cylinder of

* An excellent account of follicular mange in the dog is given in Prof. L. G. Teumann's 'Purasites et Maladies Parasitaires du Chien et du Chat.' Paris, 1914. 
pus-like matter exudes from the skin when firmly pressed. Dogs infested with follicular mange have a characteristic odour which is very foul and disgusting. 'This complaint can easily be confused with Sarcoptic mange and also with certain fungoid affections, but the presence of the mites in great numbers is a distinguishing feature. 'This form of mange is slow in progress and is not highly infectiousin fact, it is difficult to inoculate it from one dog into another. Young dogs are much more liable to be infected than older animals, and it is probable that some logs are more susceptible than others. In his interesting paper on follicular mange, Nicholson Almond, however, gives a few instances of infection taking place in adult dogs as well as puppies. The disease is more frequently met with in short-haired dogs, and sometimes occurs in a very typical form in bull terriers. As this kind of mange is very difficult to cure it is advisable to destroy infected animals unless of special value.

Cases in which human beings have been infected with skin-disease supposed to be set up by $D$. canis have been recorded by Zürn, Babès, and Lewandowsky, but these instances must be regarded as doubtful. W. H. Scott says in his paper on mange, "Perhaps I may here mention that a few days after examining three bull puppies [infected with the disease] I had developed on my own neck an erythematous patch about the size of a shilling, which was slightly irritable; a crop of papules formed, followed by pustules. A scraping of this patch revealed seven follicular acari, identical in shape and detail to those found on the dog." The species of Demodex parasitic on human bcings and that found on the dog resemble one another very closely, so that it would be easy to mistake one for the other. In any case such instances are rare, and Neumann says that persons attending to dogs suffering from demodectic mange do not contract the complaint, even if no precautions are taken. Moreover, several experimenters have attempted to transmit this parasite from dogs to human beings without result.

A large number of antiparasitical substances have been tried for the cure of follicular mange of the dog, but usually with slight success. As Mégnin has pointed out, it is difficult to think of a lotion harmless to the skin yet poisonous to the mites and at the same time capable of penetrating into the depths of the hair-follicles and sebaceous glands.

The treatment of follicular mange suggested by Gmeiner is as follows:- The hair of the affected parts and the skin round them is cut short and the places then bathed witlı a $\frac{1}{2}-1$ per cent. solution of Potassium Sulphide and afterwards treated with the following lotion: 
Ol. Carvi (Carui) 10 grammes, Alcohol 10 grammes, Ol. Ricini 150 grammes. A little of this lotion is applied on the tip of a finger and rubbed in carefully but thoronghly. Each diseased place should be rubbed with the lotion for at least three minutes so that the etherial oil can penetrate decply into the skin. The lotion should be applied once a day, and a batl in the $\frac{1}{2}-1$ per cent. solution of Potassium Sulphide should also be given once a week. $\Lambda$ fter the sulphur bath it is as well to discontinue treatment for a day or two in order to allay any irritation of the skin. The length of the treatment varies according to the nature and extent of the lesions. Cases in which the affected areas are not very large can be cured by a few weeks' treatment, but it is often necessary to devote much care and time to cases before a cure is effected.

As pointed out above, follicular mange is due to a Staphylococcus bacterium introduced by the mites and, in addition to the acaricidal treatment, vaccine treatment should also be given. Mattam cured a case of follicular mange by vaccine treatment alone, but this method is not always successful (see Smythe's paper).

The following preparations have also been used with a certain amount of succoss: 1. Potassium Sulphide and Cantharides Pomade. The dog is shaved and given a sulphur bath $(500$ grammes of Potassium Sulphiae to 100 litres of water). Then the body is rubbed with an ointment of Cantharides Pomade ( 1 part Cantharides Ointment, 6 parts Hogs' lard), a third part of the body being treated each day, so that the process is complete in three days. On the fifth or sixth day the dog is well washed, and after several days another sulphur bath is giveu and the ointment applied as before, the treatment being continued in this manner until the cure is effected. As there is danger of irritating the eyes, the skin surrounding them should only be rubbed with Balsam of Peru (diluted by the addition of four parts alcohol). 2. Carbon Bisulphide. The hair is cut short and the diseased parts dabbed with cotton wool impregnated with carbon bisulphide (the inflammable nature of the solution should be borme in mind). As soon as the surface is dry a paste composed of Formol 1-3, vaseline 50, oxide of zinc 25, starch 25, should be applied. If the skin is very thick, flowers of sulphur should be mixed with the carbon bisulphide and neutral soap powder in the respective proportions of 7,1 , and 2 . Treatment should be renewed at intervals of three or four days until a successful result is obtained. 3. Formalin solution (2-3 in 100). One or more applications every day. 4. Benzine Ointment (1 part 
Benzine to 4 parts Hogs' lard). The various methods of treatment given above are selected from a large number which have been employed by various experimenters in attempting to cope with this complaint. If not too far advanced the squamous variety of follicular mange is more radily cured than the pustular; in treating the latter the pustules should be opened and their contents pressed out before applying the acaricidal solution.

If only small areas are affected they can be excised. Bru is of opinion that if the diseased parts of the skin could be treated in such a manner that the parasites were reached by the antiseptic or antiparasitic substances used, most of those employed would be successful. He points out that Cadéac has recommended a method in which scarification is used for this purpose. All the pustules are emptied of their contents by firm pressure, the papules and thicker parts of the skin being pinched and scraped with a scalpel so as to scratch the skin, the resulting wounds being treated with $95 \%$ alcohol or diluted tincture of iodine. A somewhat similar method is that advocated by Hébrant and Antoine:-'The parts affected by the follicular mange are rubbed with a rough brush until blood makes its apperance; the surface of the skin is then dried and painted with tineture of iodine.

Heinrich Jakob records a large number of cases (117 in all) of demodectic mange in dugs, observed in a year at the Clinical Station for the Smaller Domestic Animals at Utrecht, Holland, whereas only six cases of sarcoptic mange of the dog were seen in the same period. According to Hall and Wigdor also Sarcoptes canis is much less common in the United States than Demodex canis.

Demodectic mange of the Cat.-According to Schindelka, the follicular mange of cats is very like that of the dog. It is most often present on the head, afterwards spreading to the neck. The front legs may also be affected. It is sometimes present at the same time as Sarcoptic (Notocdric) mange, and may be either of the pustular or squamous type. D. cati is sonetimes present without causing clisease, or associated with other diseases such as otitis (chancre) due to Otodectes.

Demodectic mange of the Ilorse.-Demodex equi is often present in horses which are apparently free from disease. It seems clear, however, that this species can cause a clistinct pathogenic condition of the skin, characterised either by pruritus, varying greatly in intensity, or by definite lesions; these symptoms may occur together or separately. The clinical effects are as follows:-The coat is poor, with the hair very 
sparse in places, and there are peculiar bare-looking spots (rather like the marks made by the bites of horse-lice) occurring chiefly where the hair is short; the laair on these spots is very thin, but not entircly absent. This disease usually commences on the saddle or neck of the animal. It does not appear to be at all infectious. Linzcll states that he has failed to infect clean horses by placing scrapings swarming with the mites on their skin, or even by rubbing it in. Nor does the infection seem to be spread by the rugs or other equipment. The Demodex of the horse is often found in skin complaints due to other causes, especially in Sarcoptic mange.

The following instructions for dealing with Demodectic mange in horses are adapted from Linzell's notes:-The infected animal should be thoroughly cleansed by washing or Eau de Javelle mixture, well sweated, and then massaged with a cresylated Soap-oil mixture, which should be washed off at the end of 24 hours, repeating the process in from 4 days to a week. Exercise should be given during this treatment.

The above account of the Demodectic mange of the horse and its treatment is taken from notes kindly supplied me by Lieut. Leslie Linzell, of the Royal Army Veterinary Service. In other cases (Schenzle and Bidault's observations) there are small irregular ill-defined hairless patches, more or less circular in shape, which spread, becoming confluent. They are situated on the head (on the forehead, round the eyes, parotids, etc.), afterwards spreading to the entire surface of the head. on to the chest and shoulders, etc. The skin near these patches is dry, supple, clastic, and covered with thin scales forming little crusts. The disease may also occur in a pustular form.

Demodectic mange of the horse shows a tendency to spread over the surface of the body if not treated.

According to a record compiled by Colonel WV. Pallin (as quoted by Major E. J. Wadley), Demodex was found in 4.52 per cent. in a large number of scrapings taken from Army horses suffering from contagious skin-disease (mange, etc.), or in contact with the same.

Demodectic mange of Cattle exists in the Shire Highlands of Nyasaland, where it also affects sheep, pigs, dogs, and cats. In cattle the infected animal first shows a localised nodular eruption, usually on the neck or shoulders. Later the nodules appear in grenter numbers, gradually spreading to the ears, face, trunk and upper parts of the limbs. In neglected cases the nodules may coalesce and break, discharging the purulent contents, and the irritation canses the skin to becoine harsh, thickened, and denuded of hair. 'The nodules vary 
in size from a millet seed up to the dimensions of a walnut. Numerons specimens of Demodex in various stages of development are to be found in the cheesy or fluid contents of the nodules. The above account is condensed from that of Griffiths, who states that badly infected animals should be slaughtered and the other animals dipped once a week in 1-200 Cooper's improved Cattle Dip; the cattle-sheds must also be thoroughly disinfected. Any animals suffering from the disease should be isolated.

In a later paper Griffiths points out that many of the cattle suffering from Demodectic mange are also infected with a more serions complaint, "dermatitis," due to bacteria.

Van Saceghem has seeu cases of Demodectic mange in the Belgian Congo affecting indigenous cattle, and also animals imported from Belgium and India (Zebu Cattle). The disease is characterised by comedons occurring principally round the ears, on the sides, shoulders, intercrural space, etc. The size of the comedons varies from that of the head of a pin to that of a fowl's egg. The clisease progresses slowly and does not seem to affect the general health of the animal. Infected cattle should be isolated and treated with arsenical baths. According to Van Saceghem this disease is sometimes confused with contagious dermatosis (a much more serious complaint caused by a bacterium).

The pustules, or nodules as they are called by some observers, may be situated in the thickness of the skin instead of on the surface. A large number of animals in a herd are sometimes found to be suffering from Demodectic mange, from which it would seem to be infectious. The general health usually does not seem to be much affected. It is probable that the more serious cases of disease attributed to Demodex by Geoffroy and one or two other observers, are really due to infection with some bacterium.

Stiles states that the damage to the hides due to the enlarged holes cansed by Demodex bovis lessens their value very considerably. The disease seems fairly common in the United States.

Demodectic mange in Pigs.-Stevenson says of D. phylloides that "it bores into the hair-follicles and sebaceous glands, causing pustules that enlarge, rupture, and leave sores and ulcers on the skin. This disease spreads from the snont, over the neck, the under part of the chest and abdomen, and over the flanks and inner parts of the legs; [other parts may also be affected, however]. Its deep location in the skin protects the parasite from ordinary treatment." $\mathrm{He}$ also says that "government inspectors have frcquently withheld hogs from the 
market because of a peculiar appearance of the skin which was shown to be caused by Demorlex."

At first only isolated pustules are present, their size varying from that of a grain of sand to that of a hazelnut. 'They are often very numerous and may be situated elose together; sometimes they become confluent. A very large number of mites are present in the larger pustules. The parasites are only found in places where the skin is fine in texture (see above). Some of the pustules are pigmented and may be situated rather deeply and surrounderl by an inflamed area. 'The disease does not seem to affect the general health of the animal.

Hollister states that this type of mange usually spreads very slowly, and only a few animals in the herd are affected. It is best to get rid of the infested animals ind to disinfect the premises.

The Demodectic mange of the Goat is characterised by little pustules varying from the size of a pea to that of a walnut. Sometimes they are placed on the surface of the skin but in other cases they are situated deeply and are not visible on the surface. These pustules contain a greyish matter with numerous speeimens of Demodex in all stages of development. These more deeply situated nodules are only visible when the skin of the goat is taken off (for they are situated on the inner surface); when the skin is being tanned holes appear at the places where the nodules oecur and greatly lessen its value. Aecording to Rissling (as reported by Prof. Martin*) in eertain parts of Germany the gnats of the race of Saanen are especially affeeted with this eomplaint. 'The disease seems to be infectious, for in many villages the mijority of the goats have contracted it whilst in other localities it is unknown. In treating the disease the puistules should be opened and an acaricidal fluid applied.

\section{BRIEF HISTORICAL ACCOUNT OF THE GROUP.}

Demodex folliculorum was first seen and mentioned in print $\mathrm{b}$ Henle in 1841., and was also discovered independently in the following year by G. Simon, of Berlin, who published a good deseription of this parasite under the name Acarus folliculorum. The generic name Demodex was created for it in 1843 by the celebrated zoologist Ricbard Owen, the first Director (Superintendent) of the Natural History Muscum, South Kensington. Erasmus Wilson's paper on Entozoon

* See Prof. Martin's useful paper on Demodectic Mange in herbirorous animals, Rév vétér. (Toulouse), 1913, 70* Ann., Nos. 6, 7 . 
folliculorum ( $=$ D. folliculorum) appeared in 1844, and is still of considerable value, for althongh the figures are faulty in detail, they give a good iden of the proportions of the various stages of this mite. Leydig's fine paper on Demodicidæe and Sarcoptidie was published in 1859, and contains the descriptions of D. phyllostomatis, 1). canis, and D.hominis ( $=D$. folliculorum). In 1877 and 1880 Mégnin published his observations on the family, dealing with $D$. folliculorum var. caninus (= 7). canis), var. hominis (= folliculorum), and var. catti (catti), giving many valuable details of structure, accompanied by accurate mensurements and tigures. The Demodex of the pig (D. phylloides) was found by Csokor in 1879, and his descriptions of the group and species are very interesting and of quite exceptional merit. In his 'Traité de Zoologie Médicale et Agricole' (2nd edition, 1895), liailliet gives a short résumé of the family Demodicidæ and lists the known species, giving numes to the Dernodex of the horse, goat, and sheep. The discovery of the Demodex of the mouse is due to Oudemans of Arnhem (1897), who discusses the affinities of the group, pointing out the striking resemblance to Psorergates of the family Cheletidx. The account of the family Demodicidæ by Canestrini in the 'Cierreich' is very poor and incomplete, but he gives a good description of the group and deals especially with $D$. folliculorum, D. caninus ( $=D$. canis), and D. bovis in his 'Prospetto dell' Acarofauna Italiana' (published in 1899). Professor Domenico Majocchi, of Bologna, fully discusses the relations of $D$. folliculorum with various skin-diseases in several elaborate and well illustrated papers (18791914). Finally, we have the masterly papers written by Gmeiner (1908 \& 1909) giving a list of the known species, with good measurements, etc., copious literature, and a long list of experiments dealing with the effect of various chemicals (especially the etherial oils) on Demodex.

\section{THE ORIGIN AND AFFINITES OF THE GROUंP.}

The mites of the family Demodicidx are regarded by most acarologists as an isolated group, and owing to the extreme, often vermiform elongation of the body and annulation of the abdomen, they are sometimes placed in the same suborder as the Tetrapoda (Eriophyidæ) a family also exhibiting these peculiarities but otherwise rery dissimiln. in structure. Oudemans has hinted at their derivation from the Sarcoptidæ (Astigmata) parasitic in mammals, and has also drawn 
attention to the rather close resemblance of Demodex to the Cheletid Inite Psorergates, belonging to the suborder Prostigmata. There can be little doubt that the Demodicila are closely related to the Cheletidix, and probably are a degeuerate branch of that family. The male sexual opening is dorsal in position in Demodex, being placed well forward on the cephalothorax*; and this is also well-known to be the case in the

Text-Fig. 1.

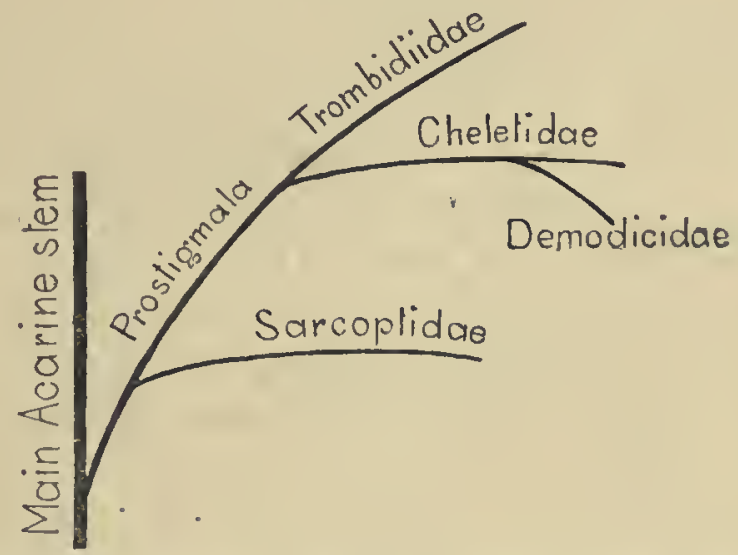

Diagram showing afinities of the family Demodicidx.

Cheletidx, notably in the genus Myolin, etc. The penis is a slender elongated structure in both these families, and usually of considerable size, being attached by the posterior end whilst the anterior end is directed forwards and upwards. Another point of resemblance is that the anus is absent in Demodex and also in the Cheletid genus Iary!yrynchus; this is no doubt due to the fact that the food of these two genera is liquid in nature and is entirely absorbed.

The mouth-parts of Demodex are very like those of Psorergates; and in the former a pair of minute ventral stigmata are present at the hase of the capitulum. It has been stated that the respiratory system is absent in the fumily Demodicida, but it is improbable that this is really the case, and I have scen intermal trachere of a very similar type tn those present in Cheleticix. It is probable that the mites of the family Demodicida were originally pilicolous mites like Myobia, etc., living at the base of the hairs of the host, and have become interual parasites, the very small size and elongation of the body being special alaptations for this mode of life. In many respects the capitulum of the Denodicilæe is very like that of Sarcoptes in structure, for as in that genus the palpi and eliclicere are completely covered both above

* See Ann. Mag. Nat. Hist. (ser. 9) Vol. i. 1918, p. 400. 
and below by a thin membranous cuticle forming the capitulum or hood; this structure is segmented in a manner ronghly corresponding with the internal parts (palpi, etc.). It is probable, therefore, that the Trombidiidæ (Cheletidx, etc.) and Demodicidx are closely allied to the Sarcoptidæ (text-fig. 1).

\section{IIABITS, ETC.}

The minute size and habit of internal parasitism of the mites of this genus make observations ou living specimens very difficult, if not impossible. They occur very frequently in the skin of mammals, and yet it is difficult to discover the way in which infection takes place. I have never seen any specimens on the outer surface of the skin, nor attached to the hairs of the host. It is, of course, possible that these parasites attach themselves to more active ectoparasites as a means of dispersal, but there is no evidence of this. It is probable that contagion is often due to actual contact or cohabitation of infected animals with others of their species.

The parasites sometimes occur in large numbers, all stages of the life-history often being present together in a follicle, thus causing it to become distended; the head of the mites usually points towards the bottom of the sebaceous gland or hair follicle. (For an account of the nymphal stages etc., see page 31 under D. muscardini.)

\section{EXTERNAL MORPHOLOGY.}

Capitulum (text-figs. 2 \& 3).-Capitulum membranous and rather delicate, enclosing the palpi, cheliceræ, etc. It shows distinct segmentation, rouglily corresponding with that of the contained palpi. Near the base there is a well-marked circular linear marking giving a ring or collarlike appearance to this part of the capitulum.' Dorsally there is a distinct triangular marking (corresponding to the epistome of the nymphal stages), the pointed apex being directed forwards. Close to the base, ventrally, there is a small central oval structure, and on either side of it there is a very minute opening. Csokor was of opinion that these are the apertures of glands, but I think it more probable that they are the stigmata or openings of the respiratory system $(q . v$. $)$. The palpi consist of three distinct segments, of which the proximal one is much the largest, the second quite short, and the third very minute; this last bears four or five rod-like setæ or spines. The proximal segment is convex on the outer sille, and when closely apposed to that of the other 
TEXT-FIG. 2.

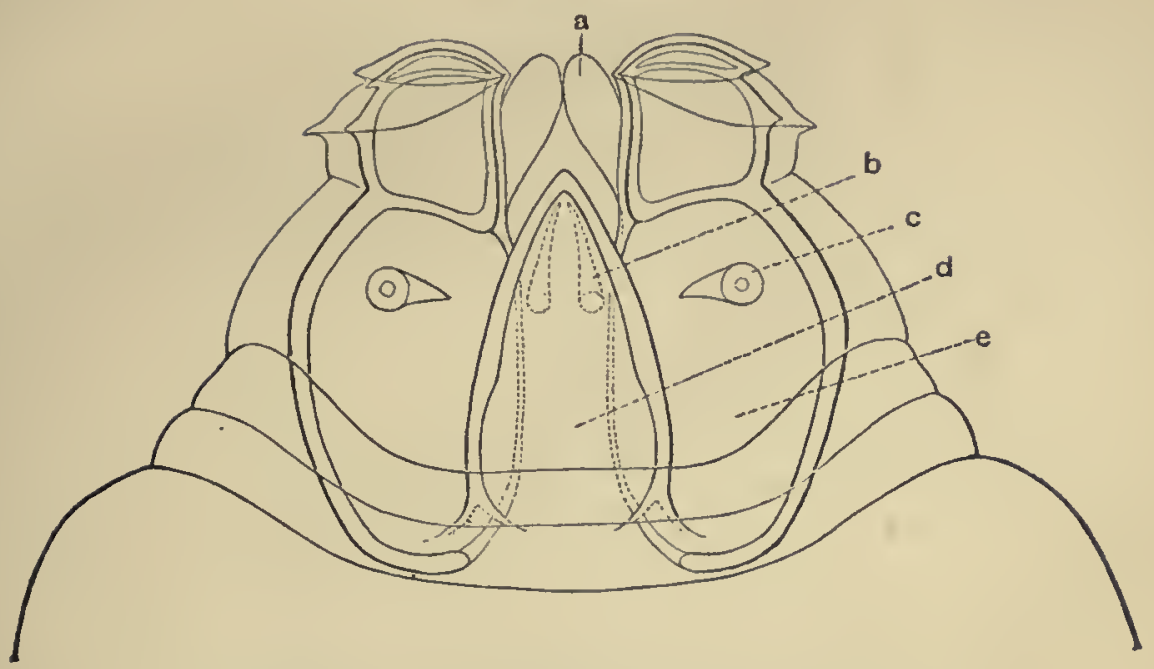

Capitulum of Democlex folliculorum, Owen, from above.

$a$. Labial sheaths of cheliceræ. $b$. Chelicera (upper finger).

c. Spine on palp. d. Epistome. e. Palp.

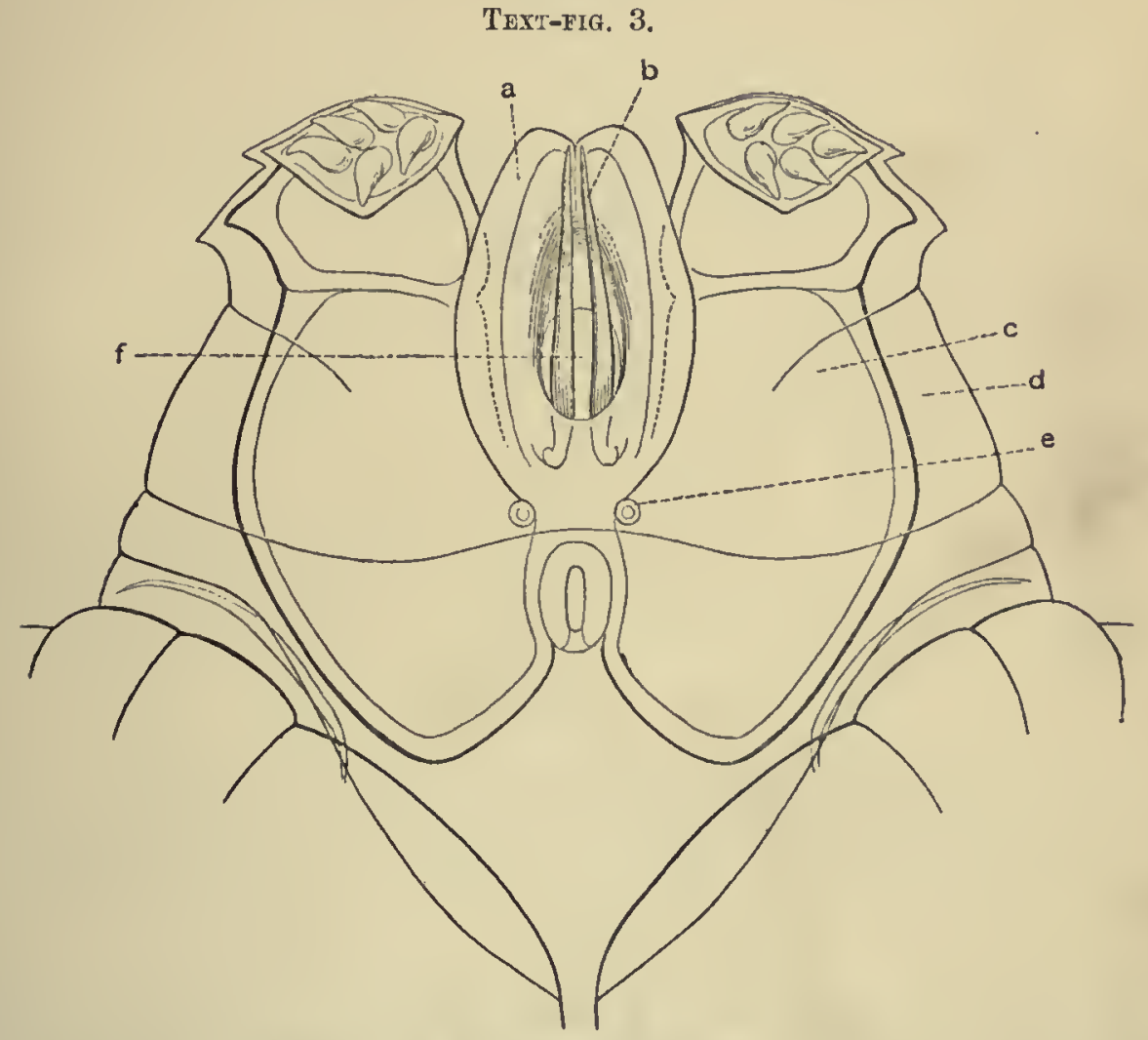

Capitulum of Demodex folliculorum from below.

$a$. Labial sheaths of cheliceræ. b. Chelicera (lower finger). c. Palp. d. Membranous capitulum. e. Supposed opening of respiratory system. f. Mouth. 
side, the palpi appear to form a single oval structure. Each palp can, however, be protruded separately, and the second and third segments are freely moveable. 'There is a well-marked tubercle or spine on this segment which differs greatly in development in the different species and affords a good specific character. It is very minute in $D$. folliculorum (text-fig. $4 \mathrm{~A}$ ) and in 7 . phylloides, and was thought to be an eye

by Erasmus Wilson, and also by Csokor. In D. canis the spine is quite sliort, curved, fairly stont at the base, the end being narrowed and pointed (text-fig. 4 B). In the Demolex of the cat the spine is like that of $D$. canis, but very minute (text-fig. $4 \mathrm{I})$ ). That of 1 . longior is very similar to the one present in $D$. canis, being short and bent, but its end is rather blunt. The spine is short and practically straight in D. bovis, but sometimes there is the merest trace of an angle quite eluse to the end; sometimes there are two slight denticles at the end (textfig. $4 \mathrm{~F} \& \mathrm{~F}$ ). In $D$. equi it is slender and rod-like, only sliglitly curved (or rather enlarged near the middle), the end blunt (text-fig. $4 \mathrm{C}$ ). That of D. muscardini is not very long, being curved, and fairly wicle

TEXT-FIG. 4.

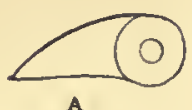

A
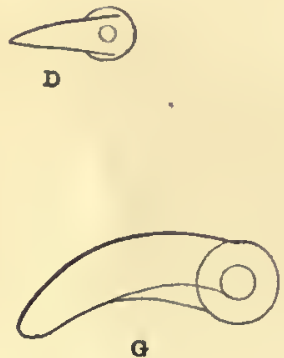

G

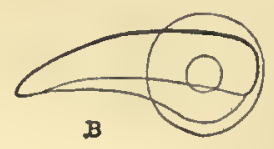

$\mathbf{B}$
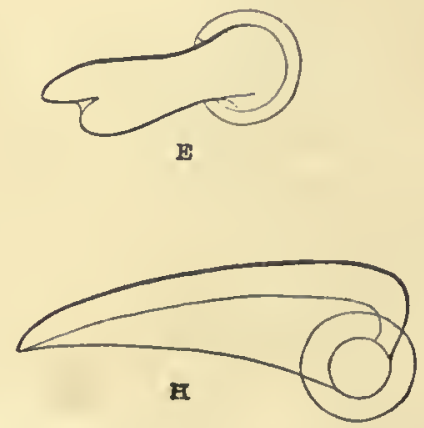
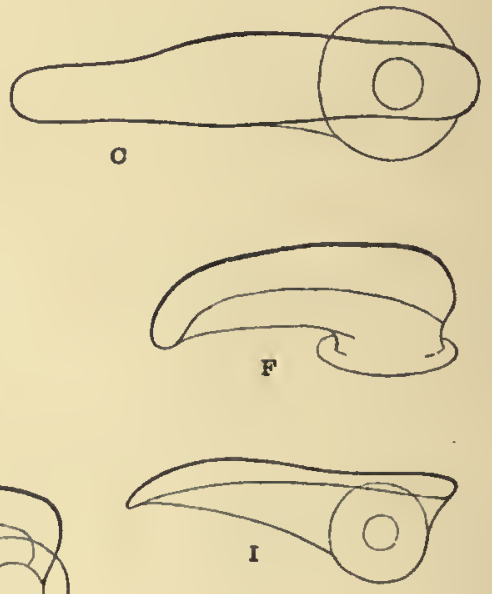

Dorsal spine on capitulum (palp) of various species of Demodex.

A. That of D. folliculorum. B. That of D. canis. C. That of D. equi. D. That of D. cati. E \& F. Spine of $D$. bovis (showing variation in form). G. That of $D$. muscarelini.

- H. That of $D$. ralti. I. That of $D$. arvicola var. musculi.

at the base, but the greater part of the length of the spine is slencier and cylindrical, the end being rather blunt (text-fig. $4 \mathrm{G}$ ). 'The spine is 
fairly well developed in $D$. arvicolce and its rarieties, being rather wide, flattened dorso-ventrally, and sharply pointed; there is a strong (often salient) angle near the base (text-fig. 4I). In D. cuniculi (possibly only a variety of $D$. arvicol(e) the spine is very similar to the one present in that species, but reduced in size. 'This type of spine is also present in D. erminece and I). ratti; in the latter, however, the spine is more elongated and the angle near the base is rudimentary (not salient) (textfig. $4 \mathrm{II}$ ). There is no spine on the palp of 7 . soricinus. The mouthparts apparently consist of two separate structures (text-figs. $2 \& 3$ ) :1. The clielicerie apparently consist of a cylindrical basal portion and two fingers or stylets, the dorsal stylet being quite short, but the ventral one very long and fine; the latter is often seen protruded, and is ealled the maxillæ by most authors, but personally, I do not think it is a separate structure. The proximal ends of the cheliceræ seem to be placed close beneath the triangular marking on the dorsal surface, and slant obliquely till they reach the ventral surface, so that the longer stylets lie almost ventrally. 2. Ventrally there is a pair of tubes lying parallel with one another and forming the sheaths of the cheliceræ; like the latter they can be protruded. Most authors are of opinion that these tubes are the cheliceræ, but this ccrtainly is not the case.

Legs.-It is usually stated in works on Acari that the lews of the Demodicidæe consist of three segments only; the great acarologist Berlese declares, however (see 'Gli Insetti,' pp. $36 \& 37$, text-fig. 26), that there are five segments, and there can be no doubt as to the correctness of his view. In well-mounted preparations of Demodex the five free segments can easily be seen, the distal ones being usually angular and rather salient on their inner surface. In addition to these there is also the fixed basal segment (coxa or epimeron). Each leg ends in a pair of claws which are provided with several minute denticles. ('The appendages of the immature stages of Demodex ( $D$. muscardini) are cleseribed in detail on page 31.)

Respiratory system.-A pair of very minute openings are present on the ventral surface of the capitulum, near the base. These apertures were noticed by Csokor, who regarded them as the openings of glands. It is more probable, however, that they are the orifices of the respiratory system. A short tube seems to lead internally from each opening, soon uniting with that of the opposite side to form a central ringlike structure; apparently after this the trachere diverge arain to form one or more main lateral trunlss, giving off smaller branclies to the 
limbs. The above account of the supposed respiratory system is given with great reserve. With the exception of Csokor, who seems to have seen the main tracher, acarologists state that there is no respiratory system in this group.

The sexual openings, penis, etc.-The accounts of the genital organs of Demodex giren by the most eminent acarolngists, are of a very divergent nature. In his 'Prospetto dell' Acarofauna Italiana,' Canestrini frankly admits that he can only distinguish the females in which developing ova are present, and he does not describe the males. Berlese is of opinion ('Gli Insetti,' vol. ii. p. 37) that the genital and anal orifices of the male Demodex are situated together at the posterior end of the ventral surface of the abdomen. Neumann follows Mégnin, and states ('Parasites et Maladies Parasitaires du Chien,' etc., p. 58) that the slit at the anterior end of the abdomen serves both for copulation and the exit of the eggs, and is larger in the female than in the male. He says there is a genital armature in front of this slit in the male sex. Mégnin says that the penis has the form of a conical tubercle, and figures it as quite a short structure (see his fig. 1, pl. xxvi., "Parasites et Maladies Parasitaires'). Csokor uses the word "Knotschen" to describe the male organ,- from which one would suppose he thought it to be quite short and like a tubercle. In reality the males of Demodex are easily distinguished by the presence of an elongated chitinous organ of comparatively large size, situated internally, which is undoubtedly the penis. It is a slender rod-like structure, attached by the hcartshaped or rather bulb-shaped posterior end, which is usually transversely striated, whilst the anterior end points forwards and upwards towards the dorsal surface. I have been able to examine specimens of D. folliculorum and of $D$. bovis which have the penis either partly or wholly protruded (see fig. 15, Pl. III. \& figs. 7, 8, Pl. II.), and have also dissected out this organ in the latter species. 'The penis usually consists of two portions or branches, one of which ends in a very fine and delicate point; the other is more blade-like, being wider and having one edge rather strongly chitinised-it is not so fincly pointed as the other half, and possibly serves as its sheath or protective guard. The penis scems to be contained in a special internal pocket or pouch in the body.

The male sexual orifice is always situated on the dorsal surface of the cephalotharax and varies slightly in position in the different species. It is usually placed above or slightly in front of the interval between the first and second legs, this being its position in $D$. folliculorum, 
D. canis, D. longior, D. cati, D. phylloides, D. bovis, and I). equi. In I). musculi the male orifice is usually situated a little further back, being above the second pair of legs, whilst in $D$. muscardini and D. cuniculi it is still further back on the dorsal surface, being placed above or slightly in front of the interval between the second and thircl pairs of legs. The male aperture is sometimes guarded by an operculum or flip, usually conical or semicircular in shape. In 7 ). bovis, and probably also in other species, the operculum consists of a median triangular lobe aud two small lateral lobes (in front), the penis pushing itself between these lobes when protruded, the lateral lobes serving to keep the penis in the right direction. Two pairs of minute but distinct swellings or tubercles are present on the dorsal surface of the cephalothorax of the male, whereas they are absent in the female; they seem too small to serve as suckers or clasping organs. These structures are figured by Mégnin (sec his 'Les Parasites', figs. 1 \& 4, pl. xxvi.). Very similar circular appearances are to be seen in Psorergates and Myobia, near the male sexual oritice-possibly they are the openings of glands.

The female sexual orifice is a distinct longitudinal slit situated at the anterior end of the ventral surface of the abdomen just behind the coxic (epimera) of the last pair of legs. It is sometines borderer by slightly elevated areas, and may be defined anteriorly by a slight curved line.

\section{TAXONOMY.}

The different forms of Demodex have bcen considered to be varieties of a single species by several authors who have studied the genus, but in reality most of them seem to be quite distinct species; some of the forms regarded as varieties in this work may, however, have to be merged as synonyms. A useful character is afforded by the pair of dorsal spines on the capitulum (or rather on the palp), for they differ in length and shape in some of the species (text-fig. 4, p. 14). 'The proportions of the body should also be taken into account, especially those of the capitulum and cephalothorax, although the former varies somewhat in the same species, its shape being slightly changed when fully protruded or retracted. On the other hand, the shiupe of the abdomen varies considerably, and can be easily altered by the mite during life, and is also casily distorted when the specimen is being mounted for the microscope. The shape of the epimera may 
differ in closely allied species. The position of the male genital orifice is also somewhat different in some of the species. The structure of the ova and immature stages should also be studied, as they serve to help to distinguish allied forms from one another. Even the adults of Demodex vary very greatly in size (especially D. folliculorum and D. canis), and it is a great mistake to rely upon measurements alone when comparing species of this genus. Some of the early workers obviously have only measured the largest specimens they met with, and it is probable that the sex of some of their specimens is wrongly given.

With the exception of $D$. bovis from the Belgian Congo, and D. phylloides from the Argentine, all the forms of Demodex dealt with below are described from examples from English hosts. 'The measurements were made with a Zeiss Stufen (step) ocular micrometer, the values of the scale being obtained in the usual way by combination with a stage micrometer. The figures have been carefully drawn by Mr. Percy Highley with the aid of an Abbé camera lucida.

\section{LIST OF THE SPECIES AND TARIETIES OF THE GENUS DEMODEX WITH THEIR HOSTS AND KNOWN DISTRIBUTION.}

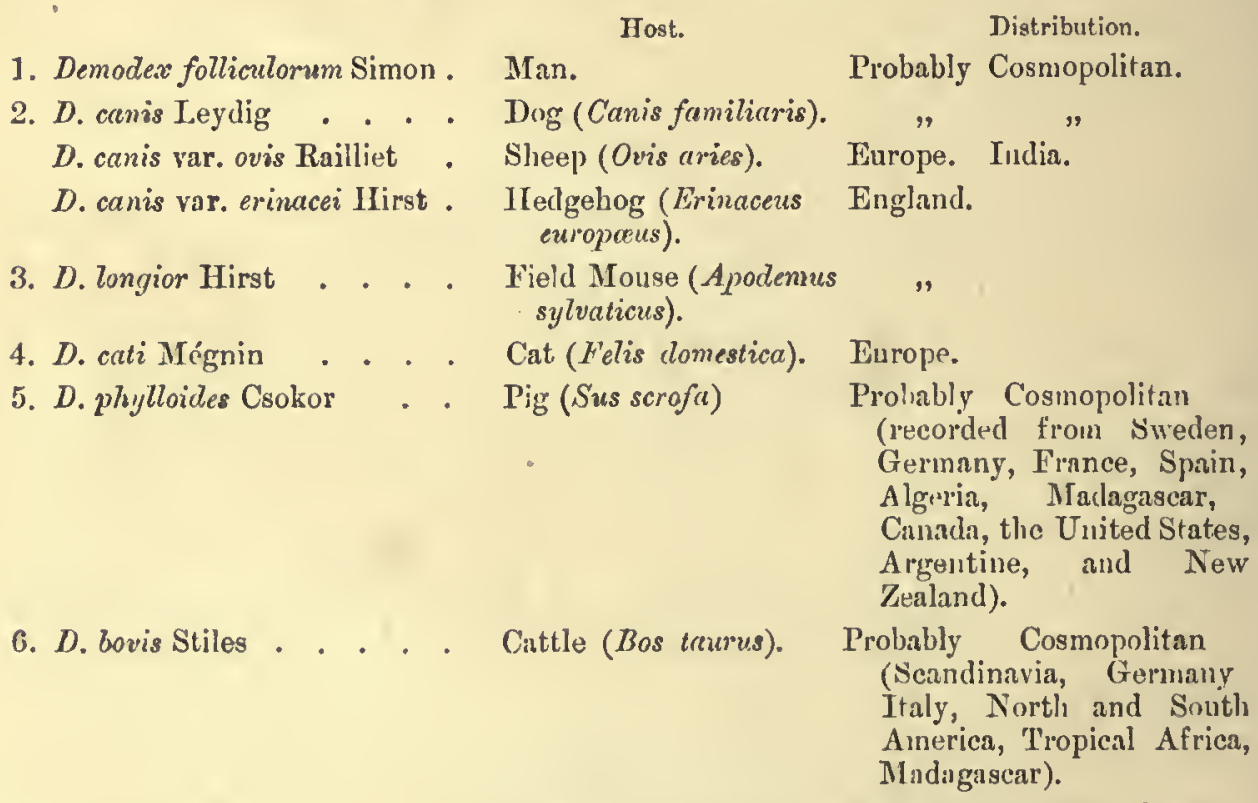

7. D. equi Raillict . . . . Horse (Equus caballus). Probably Cosinopolitan (Srotiand, Fngland, I'rance, Germany, Brazil). 
8. Host. Histribution.

8. D. muscarlini llirst . . Dormouse (Afuscarclinus England.

9. D. erminere, sp. n. . . . Stont (Mustela erminea).

10. D. arvicola Zschoklie . . Field Vole (Miciotus [Arvicola] rgrestis). Europe.

D. arvicole var. inusculi House Mouse (Mus musOudemans. culus).

D. arvicolce var. apodemi Field Mouse (Apodemus England. Hirst.

D. arvicale var. glareoli, BankVole(Fivotomysglareo- ", var. nov.

11. D. cuniculi Pfeiffer . . . Rabbit (Oryctolayus cuni. " and China.

12. D. rutti Hahn . . . . Brown Rat (Rattus nor- Europe. vegicus).

13. D. soricinus Hirst . . Black Rat (Rnttus rattus) Englaud. and Brown Rat (Rathes norvergicus). Shrew (Soresc uraneus castaneus).

The following three forms of Demodex have not been seen by the author:-

14. D. cupre Railliet . . . . Goat (Capra hircus). Europe.

15. D. cervi Prietsch . . . . Sambar Deer (Cervus sp.). Loc.?

16. D. phyllostomatis Leydig - Bat(Phyllostoma hastatum). Surinam.

Democlev is also known to occur in the Barbary Ape, in the Fox aud Siberiau Marmot, but the forms concerned npparently have not been described.

\section{Order ACARI.}

Suborder VEIRIFORMIA PROSIIG II TA.

Family DEMODICIDE.

Genus DEMODEX, Owon, 1843.

1. DEMODEX FOrLICULORUM, G. Simon, 1843.

(Plate I. figs. 1-3 ; and Plate III. figs. 12, 14, 15.)

Acarus folliculorum, G. Simon, Areh. Anat. Pliysiol. Med. 1843, p. 218.

Demodex $f$., Owen, Lect. Invert. Anim. 1843, p. 252.

Mucrogaster platypus, Miescher, Ber. Ges. Basel, 1843, vol. v. p. 191.

Simonea follioulorum, Gervais, Ins. Apt. 1844, vol. iii. p. 282.

Entozoon f., Wilson, E., Phil. Trans. Roy. Soc. 1844, p. 305.

Steatozoon $f .$, Ib., On Diseases of the Skin, 1847.

D. Icominis, Leydig, Arch. Naturg. 1859, Jahrg. i. vol. xxv. p. 235. 
7). f., rar. hominis, Mégnin, Parasites, 1880, p. 267.

II. f., G. Canestrini, Prospett. Acarof. Ital. 1899, part 8, p. 965.

D. f., Brrlese, Gli Insetti, 1912, vol. ii. p. 36.

․ Adult females of D. folliculorum (from human beings) are from about $4 \frac{1}{2}$ to over $7 \frac{1}{2}$ times as long as the width of the cephalothorax. Intermediate forms between these two extremes are of conrse met with, some being a little more tiran five times, others about $6 \frac{1}{2}-6 \frac{3}{4}$ times as long as the cephalothoracic width. Abdomen in short forms sometimes considerably less than twice the combined length of cephalothorax and capitulum; in other specimens the abdomen is about twice the length, and in very elongated examples $2 \frac{1}{2}-3$ times the length of cephalothorax + capitulum. Erasmus Wilson figures some still more elongated forms; see his figs. 1-3, 6, and especially fig. 33. This species is indeed the longest of the genus, females sometimes measuring up to $390 \mu$, and there is one specimen of this sex in the British Museum collection which measures $440 \mu$, but it has been slightly pressed by accident and is a little distorted.

\$. Adult male specimens of $D$. folliculorum vary very greatly in size, some specimens being very elongated whilst others are quite short. The largest example examined by the anthor is a little less than six times as long as the width of its cephalothorax, the abdomen being abont two and a half times as long as the cephalothorax. In very short specimens the body is sometimes from only a little more than three times up to more than four times the cephalothoracic width, the abdomen being considerably less than twice the length of the cephalothorax. The smallest specimens of this sex have a very short tail, and thus resemble $D$. plyylloides somewhat in general appearance. 'lhis short caudate form is well figured by Erasmus Wilson (see his figs. 4 \& 5, pl. xv. and 40-42, pl. xvii. Phil. Trans. Roy. Soc. 1844). One or two specimens of this caudate form were met with which showed no trace of sexual structures and are, perhaps, subadult males; others have the penis and sexual aperture well developed. It is probable that this form is a stage through which all males of this species have to pass before becoming fully developed and elougaterl. Penis not very long; it forks to form two branches in much the same way as that of $D$. Lovis, one of the branches being apparently wider, flaster, and blunter than the other. The male sexual orifice scems to be much simpler than in $D$. bovis, being merely surrounded by circular wrinkles of the skin; it is situated above and just behind the trunsverse groove between the epimera of first and second legs. 
Larva.-Slender elongated larve of this species are sometimes met with, and they may reach a great length $(430 \mu)$, being up to $\delta \frac{1}{2}$ times as long as their greatest width; thrce pairs of ridge-like lateral appendages (epimera) are present, and they bear the usual pair of tiny spinulose tubercles; the outer side of each epimeron projects as a strong spine or process. Smaller specimens of this slender larval form apparently sometimes have only a single median tubercle on the epimeron instead of two. Nearer the middle ventrally there are the three usual pairs of lobes, the anterior pair being especially minute, whilst the last (posterior pair) are somewhat longer than the middle pair. Capitulum well defined, each of the three segments projecting a little laterally so as to form a short but distinct spine. G. Simon figures a larva of this elongated type, but makes the mistake of showing the legs as segmented. It is also figured by Erasmus Wilson (his figs. 24, 26 , \& 27). This elongated type of larva could easily be mistaken for the nymph, but it has only three pairs of appendages. It is remarkable that larvæ should reach such a comparatively large size. The smaller larval and nymphal stages of this species have not been examined by the author, but they are figured in Erasmus. Wilson's paper.

Nymphs.-Elongated nymphal forms very similar to the larve in general appearance are sometimes found, but they have four pairs of lateral appendages and four pairs of rentral discs (instead of only three as in larve). The epimera slow traces of segmentation, being divided into two by a transverse line; the usual pair of spinulose tubercles are present on their surface. Some of these elongated nymphs are uearly seven times as long as their greatest width. A specimen containing a fully developed adult measures about $340 \mu$, but still larger deutonymphs may be met with.

Author's measurements :-

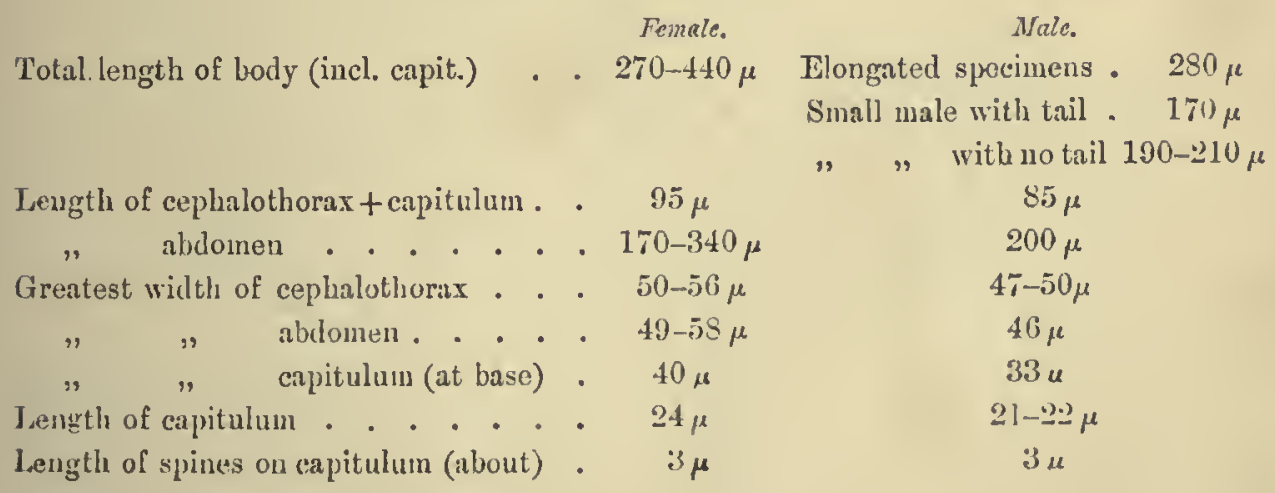


Elongated Larral Form.

Tolal length (incl. capitulum) of longest specimen . . . . . . . $430 \mu$

Greatest width of body . . . . . . . . . . . . . . $48 \mu$

" $"$ capitulum (at base) . . . . . . . . . $25 \mu$

Length of capitulum . . . . . . . . . . . . . . $22 \mu$

Elongatod Nymplis.

Total length (incl. capitulum) . . . . . . . . up to $410 \mu$

Canestrini gives the following measurements of the Demodex occurring in human beings:-

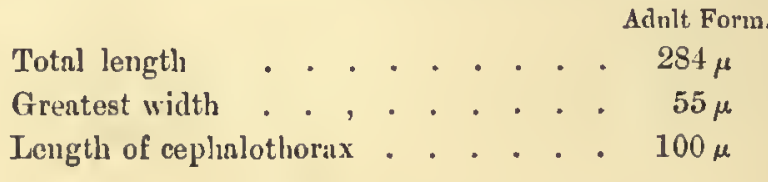

The following average measurements of this species are given by F. Gmeiner in his paper on Demodex:-

\begin{tabular}{|c|c|c|c|c|c|c|c|c|c|c|}
\hline \multirow[b]{2}{*}{ Total length of body } & \multirow[b]{2}{*}{ • } & \multirow[b]{2}{*}{ • } & \multirow[b]{2}{*}{ - } & \multicolumn{4}{|c|}{ Female. } & \multicolumn{3}{|c|}{ Male. } \\
\hline & & & & - & $\cdot 36$ & & $m m$. & & $\cdot 3$ & $\mathrm{~mm}$. \\
\hline Length of capitulum & . & & . & - & $\cdot 02$ & & , & & $\cdot 02$ & $"$ \\
\hline Width " $"$ & - & & - & & .037 & & $"$ & & $\cdot 03$ & $"$ \\
\hline Teugth of thorax & . . & - & . & . & $\cdot 09$ & & , & & $\cdot 085$ & $"$ \\
\hline Width $\quad " \quad$. & • . & • & . & . & $\cdot 05$ & & $"$ & & $\cdot 045$ & $"$ \\
\hline Length of abdomen . & . . & - & . & . & $\cdot 25$ & & $"$ & & $\cdot 195$ & , \\
\hline Length of egg & . & & . & . & .. & - & . & $.08 n$ & m!n. & \\
\hline Width " . & • & & . & & . & . & . & $\cdot 04$ & $"$ & \\
\hline Length of six-le & gge & & va & & - & , & . & $\cdot 12$ & $"$ & \\
\hline Width $\quad "$ & & & , & & . & - & - & $\cdot 05$ & , & \\
\hline Length of nym & & & ${ }^{\circ}$ & • & - & - & - & $\cdot 36$ & $"$ & \\
\hline Width $\quad "$ & & . & . & - & . & . & . & .04 & $"$ & \\
\hline
\end{tabular}

Mégnin's measurements (in mm.) of D. folliculorum are as follows:-

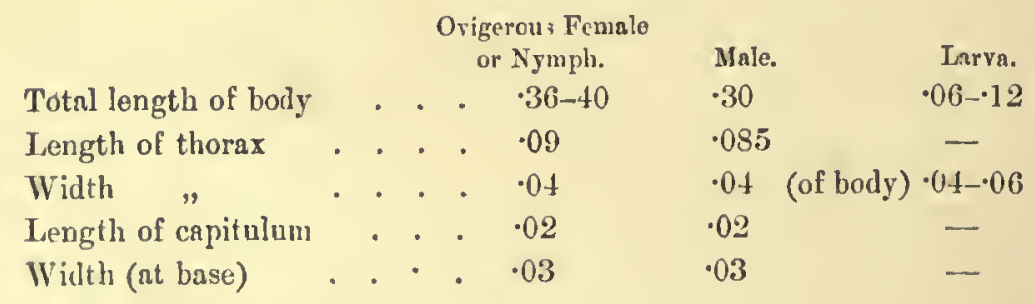

Hust: Man. 
2. DENODDE CANIS, Loydig, 1859.

(Plate I. figs. 4 \& 5.)

D. folliculomen, Tulk, Ann. Mag. Nat. Hist. 1844, vol. xiii. p. 75.

D. canis, Leydig, Arch. Naturg. 1859, Jilırg. i. vol. xxv. p. 345.

D. folliculorum var. caninus, Mégnin, J. Anat. Physiol. 1877, vol. xiii. p. 111.

D. caninus, Canestriui, Prospetto dell' Acarofauna Ital. 1899, part 8, p. 966.

9. D. canis is an elongated species, bcing usually more than six (sometimes up to seven) times as long as wide. The cephalothorax (not including capitulum) is a little less than half the length of the abdominal part of the body and is of moderate width. Abdomen long and slender, gradually tapering to the posterior end, which is bluntly pointed. Capitulum of moderate width, being widest at the base, where it is slightly wider than long; the two spines on its dorsal surface are very short and pointed.

\%. Size very variable, specimens of this sex being sometimes much shorter than females. Male sexual orifice situated above the interval between the first and second legs. Penis rather long, slender, and usually curved.

Egg spindle-shaped.

Author's measurements :-

Female.

Total length of body (incl. capit.) . . . . . 180--264 $\mu$

Length of cephalothorax + capitulum . . . -

" abdomen . . . . . . . . . -

r. $\cdot . \cdot 40 \mu$

" $" \quad$ abdomen $\quad \cdot \quad \cdot \quad \cdot \quad \cdot \quad \cdot \quad \cdot \quad-$

Length of capitulum . . . . . . . . $27 \mu$

" spines on capitulum . . . . . $4 \mu$

Canestrini's measurements of $D$. canis ale as follows :-

$\begin{array}{ccccc} & \text { Adult form. } & \text { Nympb. } & \text { Larva. } & \text { Orum. } \\ \text { Total length . . . . . } 302 \mu & 239 \mu & 137 \mu & 10 \mu \\ \text { Length of cephalothorax } & \text { - } 110 \mu & - & - & - \\ \text { " abdomen . . . . } 192 \mu & - & - & - \\ \text { Greatest width . . . . . } 45-55 \mu & 45 \mu & - & 4 \mu\end{array}$

Mégnin gives the following measurements of $D$. canis:-

\begin{tabular}{|c|c|c|c|c|c|c|c|c|}
\hline & & & $\begin{array}{r}\text { Ovigero } \\
\text { femal }\end{array}$ & & Male. & $\begin{array}{l}\text { 1st Larva } \\
\text { (apodous). }\end{array}$ & $\begin{array}{l}\text { 2nd Larva } \\
\text { (hexapod). }\end{array}$ & $\begin{array}{c}\text { Nymph } \\
\text { (octopod). }\end{array}$ \\
\hline Total length of body & • & . & $\cdot 25-\cdot 30$ & $\mathrm{~mm}$. & $\cdot 22-\cdot 25$ & $.06-.09$ & $\cdot 11$ & $\cdot 19$ \\
\hline Length of thorax & . & • & $\cdot 10$ & $\eta$ & .095 & - & - & 一 \\
\hline Width $\quad$, & . & . & .045 & $"$ & $\cdot 045$ (of body) & $\cdot 015-.025$ & .032 & $\cdot 0.1$ \\
\hline Tength of crpitulum & . . & . & $\cdot 03$ & , & $\cdot 03$ & - & - & - \\
\hline Wilth & (at basse) & . & $\cdot 03$ & $"$ & $\cdot 03$ & - & 一 & 一 \\
\hline
\end{tabular}


U. crmis.-Gineiner gives the following average measurements of this species:-

\begin{tabular}{|c|c|c|c|c|c|c|c|c|}
\hline \multirow[b]{2}{*}{ Total length of body } & \multirow[b]{2}{*}{. . } & & \multicolumn{3}{|c|}{ Female. } & \multicolumn{3}{|c|}{ Male. } \\
\hline & & & & & & & .25 & \\
\hline Length of capitulum & & 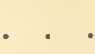 & & .035 & $"$ & & $\cdot 03$ &, \\
\hline Width ", & & - & & $\cdot 03$ & , & & .03 & , \\
\hline Length of thorax & & & & $\cdot 105$ & $"$ & & .078 & $"$ \\
\hline Width $\quad "$ & & . & & $\cdot 045$ & ", & & .04 & 5 \\
\hline Length of abdomen & . & & - & $\cdot 10$ & $"$ & & $\cdot 14$ & 5 \\
\hline Length of egg & . & . & & . & . . & .95 & $\mathrm{~mm}$. & \\
\hline Widtb, & . & & & . & . . & .025 & 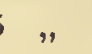 & \\
\hline Length of six-le & & 1 larva & & . & . . & $\cdot 14$ & $"$ & \\
\hline Width " & & $"$ & & . & . & .035 & , & \\
\hline Length of nym & & & & & . . & .23 & " & \\
\hline Width & & & & & . . & .05 & , & \\
\hline
\end{tabular}

Ifust: The Dog (Cunis familiaris).

DEMODEX CANIS raR. OVIS, Raill. 1895.

D. folliculorum var. ovis, Railliet, Zool. Méd. Agric. 1895, 2nd Ed., p. 638 .

(Plate III. fig. 13 ; Plate 1V. fig. 16.)

q. The Demodex of the sheep is a slender elongated form, very similar to $D$. canis in most respects, but slightly shorter, and with the capitulnm rather wider, for it is very distinctly wider than long. Body from $5 \frac{1}{2}$ to almost seren times as long as the width of the cephalothorax. Abdomen considerably longer than cephalothorax + capitulum; in elongated specimens it measures up to about twice their combined length. Dorsal spines of capitulum quite short as in D. canis.

Author's ineasurements:--

\begin{tabular}{|c|c|c|c|c|}
\hline Total length of body (inel. capitulum) & & & . & $\begin{array}{c}\text { Fenale. } \\
221-233 \mu\end{array}$ \\
\hline Length of eeplatothornx + capilulum & . & & . & $87-94 \mu$ \\
\hline *, abdomen $\quad . \quad . \quad . \quad$. & - & & . & $134-139 \mu$ \\
\hline Grentest width of eephalothorax & . & & . & $44 \mu$ \\
\hline$" \quad, \quad$ abdomen . . . & . & & . & $45 \mu$ \\
\hline$" \quad \quad \quad \quad$ capitulum (at base) & & . & . & $29 \mu$ \\
\hline Length of eapitulum..... & . & & . . . & $22 \mu$ \\
\hline Spines on eapitulun & . & & abunt & $3 \mu$ \\
\hline
\end{tabular}

Host: Sheep (Ovis aries). Several adult female specimens from the eyelids of a fieshly killed sheep.

Note.-Majoechi considers the Demodex of the sheep to be identical with that of the dog, and it is possible that he is right. 
DEMODEX CANIS vAr. ERINACEI, Hirst, 1917.

D. erinacei, Hirst, Ann. Mag. Nat. Hist. (ser. 8) vol. xx. p. 434.

(Plate IV. figs. 17, 20, 21.)

오. The Demodex occurring in the hedgehog is an elongated form closely resembling that of the dog (D. canis) in almost every respect, but of largel size and with the capitulum wider as compared with its length, being very distinctly wider than long (at the base), instead of only slightly wider as in $D$. canis; the sculpturing of the dorsal surface of the capitulum apparently is also rather different; the two spines are much like those present in $D$. canis, being quite short. looly from over six to slightly more than seven times as long as wide. Cephalothorax + capitulum about a third of the total lengtl. 'Transverse striations of body cxtending forwards beyond the coxic of the fourth pair of legs, the first striation being deep and well-defined.

б. Body long and slender, as in the female, being a little more than six times as long as the width of the ceplialothorax. Abdomen a little more than twice the length of the cephalothorax + capitulum. Malc sexual orifice placed well in front of the transverse furrow betwecn corie of first and second pairs of legs. Penis very long and slender.

Author's measurements-

\begin{tabular}{|c|c|c|c|c|}
\hline Total length of body (incl. capit.) & - & & $\begin{array}{l}\text { Female. } \\
313-335 \mu\end{array}$ & $\begin{array}{c}\text { Male. } \\
\text { about } 330 \mu \\
\text { (specimen slightly bent). }\end{array}$ \\
\hline Length of cephalothorax + capitulum & . & . & $108 \mu$ & $116 \mu$ \\
\hline , abdomen . . . . . & . & . & $205 \mu$ & about $214 \mu$ \\
\hline Greatest width of cepbalothorax & . & . & $4+\mu$ & $53 \mu$ \\
\hline " $" \quad$ abdomen ... & . & . & $46 \mu$ & $?$ \\
\hline , capitulum (at basc) & & . & $35 \mu$ & $42 \mu$ \\
\hline Length of capitulum . . . . . & . & . & $26 \mu$ & $29 \mu$ \\
\hline " penis . . . . . & . & . & - & $32 \mu$ \\
\hline
\end{tabular}

IIcst: Iledgehog (Erinacens europreus). Several specimens were obtained from an Englisb example of this animal.

3. DEMODEX LONGIOR, Hirst, 1918.

Ann. Mag. Nat. Hist. 1918 (ser. 9) vol. ii. pp. 145 \& 146.

(Plate IV. figs. 18 \& 19.)

ㅇ. An clongated species of comparatively large size, resembling D. cenis in many respects, but the coxæ (epimera) of the legs are narrower and produced posteriorly, especially the first ones. Body 
sometimes nearly nine times as long as the width of the cephalothorax. Abdomen about $2 \frac{2}{3}$ times the combined length of cephalothorax and capitulum. Capitulum wider than long; the spines on its dorsal surface are short and somewhat curved.

б. Abdomen about twice as long as the cephalothorax+capitulum. Body more than 6 times as long as the cephalothoracic width. Male sexual orifice situated above the interval between the legs of the first and second pairs.

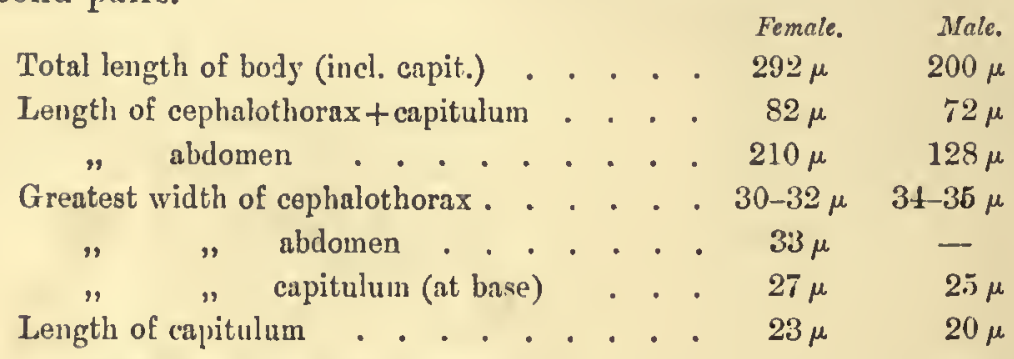

Host: Field Mouse (Apodemus sylvaticus).

Nort.--In one male specimen the tracheal tubg leading from the capitulum are quite distinct; each is at first double but the two parts afterwards fuse to form a single wide lateral main trunk.

\section{DEMODEX CATI, Mégnin, 1877.}

Journ. Anat. Physiol. 1877, vol. xiii. p. 112.

(Plate V. fig. 23.)

$\delta$. Body elongated, being almost $5 \frac{1}{2}$ times the cephalothoracic width. Abdomen about $1 \frac{1}{2}$ times as long as cephalothorax + capitulum, its posterior end pointed. Capitulum wider than long; spines on its dorsal surface of the same type as in $D$. canis, but very minute and inconspicuous. Male genital orifice placed above and in front of legs of second pair.

ㅇ. Body very elongated; capitulum as in male, but as wide as long. [Female specimens too damaged for a more detailed description.]

Author's measurements :-

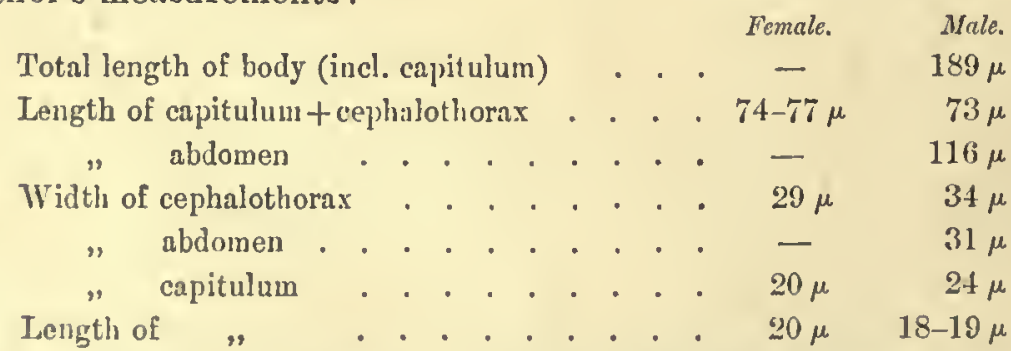

Host: The Cat (Felis domestica). A perfect male specimen and a few danaged specimens collected by the author from a London cat, which did not show any signs of skin-discase. 


\section{DEMODEX PHYLLOIDES, Csokor, 1879.}

D. phylloides, Csokor, Oest. Vierteljahrschr. f. Veterinärk., 1879, vol. li. p. 133.

D. folliculorum var. suis, Railliet, Zool. 2nd Ed. 1895, p. 637.

D. plylloides, Canestrini, Prospetto dell' Acarofauna Ital. 1899, part 8, p. 968.

$$
\text { (Plate V. figs. 22, 24) }
$$

․ D. phylloides is a short and rather wide species, the total length of the body being about three and a half times as long as the width of the cephaluthorax. Abdomen a little longel than cephalothorax + capitulum, and its posterior end abruptly narrowed to form a short tail-like process. Capitulum a little wider than long; tubercles on dorsal surface very short and inconspicuous.

o. Male sexual orifice situated dorsally just in front of transverse groove between first and second legs. Penis fairly long.

Author's measurements :-

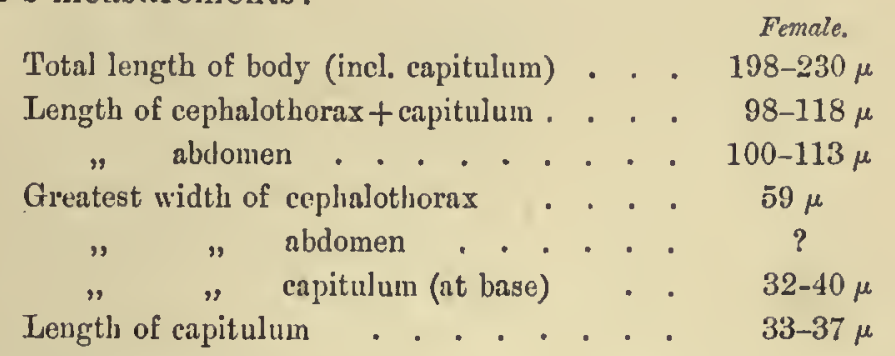

According to Gmeiner, arerage measurements of D.phylloides are as follows:-

\begin{tabular}{|c|c|c|c|c|c|c|c|c|c|}
\hline \multirow{2}{*}{\multicolumn{2}{|c|}{ Total length of body }} & & & & & \multicolumn{3}{|c|}{ Female. } & \multirow{2}{*}{$\begin{array}{l}\text { Male. } \\
.22 \text { mın. }\end{array}$} \\
\hline & & & . & & . & .24 & $\mathrm{mn}$ & & \\
\hline Length & eapitulum & . & . & . & . & .04 & 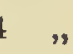 & & 039 \\
\hline Width & $"$ & . & . & . & & $\cdot 03$ & 35 & & . 036 , \\
\hline Length o & thorax & . & . & . & . & .07 & 7 & & .061 , \\
\hline Width & & . & . & . & . & $\cdot 06$ & ," & & .057, \\
\hline Length & abdomen & 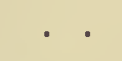 & . & . & & $\cdot 13$ & $"$ & & -12 , \\
\hline & Length of & egg & . & & & & .05 & $\mathrm{mun}$. & \\
\hline & Width & & & . & & . & $\cdot 02$ & 3 & \\
\hline & Length o & larva & . & . & . & . & $\cdot 14$ & " & \\
\hline & Width & & . & . & & & .04 & $"$ & \\
\hline & Length 0 & nymph & • & . & • & . & $\cdot 26$ & ", & \\
\hline & Width &, & & & . & . & $\cdot 06$ & , & \\
\hline
\end{tabular}

Hest: The Pig (Sus scrofa). Numerous specimens from minute boils in the hide of a pig from the Argentine. This naterial is preserved in spirit and was presented to the Museum by Lt.-Col. A. W. Alcock, F.R.S., of the London School of Tropical Medicine (see also Dr. H. B. Newham's paper " which deals with the same material). 


\section{DEMODEX BOVIS, Stiles, 1892.}

I). folliculorum var. boris, Stiles, Canad. Ent. 1892, vol. xxiv. p. 286. D. bovis, Canestrini, Prospetto dell' Acarofuuna Ital. 1899, part 8, p. 967.

(Plate I. fig. 6; Plate II. figs. 7 \& 8 ; Plate V. figs. 25, 26 ; Plate VI. fig. 30.)

․ D. bovis is a short and fairly wide species, closely resembling D. equi in general appearance and also rather like D. phylloides. Body from a little more than three up to more than three and a half times (rarely up to nearly four times) as long as wide. Abdomen a little longer than cephalothorax + capitulum, the end being distinctly pointed and sometimes almost tail-like. Capitulum short and wide, being much wider than long; spines on its dorsal surface rather short, a little curved and pointed.

7. Male usually a little larger than female, and with a most distinct caudal process. Body $3 \frac{1}{2}$ up to $3 \frac{3}{4}$ times (or even 4 times, but this is exceptional) as long as the width; the abdomen usually ends in a short but distinct tail-like process, and is considerably longer than cephalothorax +capitulum. Waist or constriction between cephalothorax and abdomen often well-marked. Penis rather long; it has a short enlarged basal portion and the slender distal part is bifid, consisting of two branches, one of which ends in a very fine and sharp point, the other is wider and more blade-like, being more strongly chitinised and blunter at the tip. Genital opening of male above and in front of the groove between coxæ (epimera) of first and second legs. The operculum consists of a median triangular lobe and two small lateral lobes between which the penis is extruded.

Deutonymph. The final nymph containing the developing last stage (adult) reaches a large size in this species, being very elongated and from less than four up to slightly more than five times as long as wide. 'The anterior part of the body is rather wide, but the posterior end is much narrowed so as to form a long slender tail. Palp with the last segment conical and bearing three or more strong claw-like spines at the end. The four pairs of lateral platelets or epimera are not very distinct in preserved specimens; they each bear exceedingly minute but distinct little cones furnished with three or more sharp denticles. A little to the inner side of these epimera there are the usual two series of four little discs with the posterior margin curved.

Egg oral in shape. 
Author's measurements:-

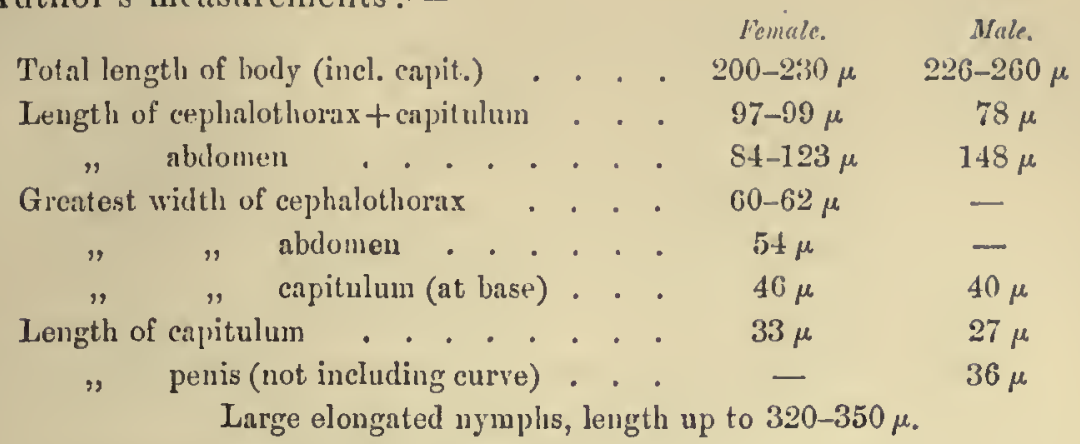

Canestrini's specimens of $D$. bovis were of the following dimensions:-

\begin{tabular}{|c|c|c|c|c|c|c|}
\hline Total length & • & - & $\begin{array}{l}\text { Adult. } \\
247 \mu\end{array}$ & $\begin{array}{c}\text { Nympl. } \\
375-50 \pm \mu\end{array}$ & $\begin{array}{l}\text { Larva. } \\
28 \pm \mu\end{array}$ & $\begin{array}{l}\text { Orum. } \\
10 \mu\end{array}$ \\
\hline Length of cephalothorax & $x$. & . & $110 \mu$ & - & - & - \\
\hline abdomen & - . & . & $137 \mu$ & - & 一 & - \\
\hline ", capitulum & • & . & $2+\mu$ & - & - & 一 \\
\hline Greatest width . . & - & : & $64 \mu$ & - & 一 & $5 \frac{1}{2} \mu$ \\
\hline Width of capitulum & . & : & $24 \mu$ & - & -_ & $\ldots$ \\
\hline
\end{tabular}

D. hovis has the following average dimensious according to Gineiner :-

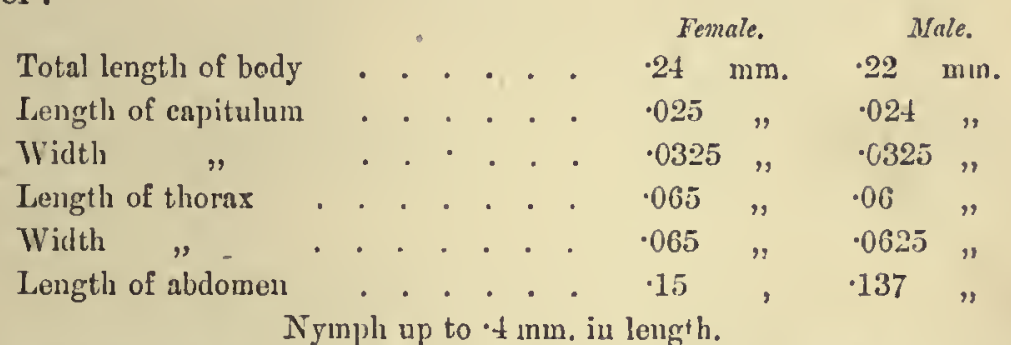

Host: Cattle (Bos taurus). The specimens described above wcre collected from A frican cattle at Zambi, Bas-Congo, by M. R. Van Saceghem (Director of the Veterinary Laboratory at that locality), who kindly presented them to the Museum. They are well preserved in alcohol and g'ycerine, but' some are slightly distended by the preservative, and it is possible that the dimensions are slightly altered.

\section{DEMODEX EQUI, Railliet, 1895.}

Demodex folliculorum var. equi, Railliet, Zool. 2nd Ed., 1895, p. 639.

$$
\text { (Plate II. figs. 9-11.) }
$$

․ This species is much wider than is usually the case in the genus, the wilth of the cephalothorax (in mounted specimens) being about a third or slightly more than a third of the total length; the part of the body bearing the fourth pair of legs is the widest. Cephalothorax+ capitulum longer than abdomen; the latter has the posterior end romded off or else bluntly pointed. Capitulum distinctly wider than 
long; the two spines on its dorsal surface are not very long, but slender and rod-like, being almost straight in this sex, parallel, and blunt at the end.

o. Abdomen usually considerably shorter than cephalothorax +capitulum. Other proportions of borly much as in the female. Dorsal spine of capitulum apparently more curved than in the female. Nale sexual orifice situated above and slightly in front of the transverse groove between the first and second pairs of Jegs. Penis long, slender, and usually curved; just before the end it has the appearance of being narrowed to form a short neck, the end itself being shaped like the flame of a candle.

Author's measurements :-

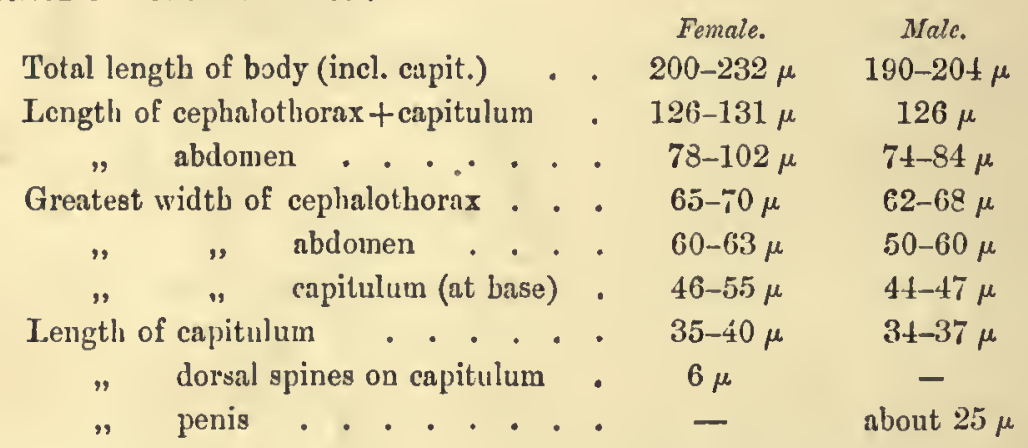

Host: The Horse (Equus cabullus). I have examined eleven females and three males of this species from English horses (Leslie Linzell's collection).

\section{DEMODEX MUSCARDINI, Hirst, 1917.}

D. muscarlini, Hirst, Ann. Mag. Nat. Hist. (ser. 8) vol. xx. 1917, pp. 433-434.

(Plate VI. figs. 27-29; Plate VII. figs. 31-33;

Plate VIIl. figs. 35, 36.)

q. This Demodex is a short form, and very like that of the housemouse, but the capitulum is wider as compared with its length and armed with differently shaped spines. The general shape of the body is also rather different in this species. Width of cephalothorax a little more than four times up to four and a half times the total length of the body (incl. capitulum). Cephalothorax+capitulum a little less than the length of the abdomen. Capitulum rather short, being wider than long (at the base). Spines on dorsal surface of capitulum rather short, curved, the end narrowed. Penultimate segment of palp salient and pointed laterally, as in D. musculi.

o. Body a little less than four times up to a little more than $5 \frac{1}{2}$ 
times as long as wide. Capitulum + cephalnthorax about as long as the abdomen. Genital opening situated further back on the dorsal surface than is usually the case in the genus, being placed above the transverse groove between the second and third pairs of legs. Penis short but slender.

Deutomymphs. - The older nymphs are elongated, and the posterior end of the abdomen is usually pointed. Their capitulum is shorter and narrower than is the case in the protonymphs. The proportions of the body vary very much, according to size and degree of development. In small specimens the body is from $3-4 \frac{1}{2}$ times as long as the greatest width. A larger specimen of this stage (containing an almost fully developed specimen of the final or adult stage) has the abdomen a little longer than the cephalothorax + capitulum, and the total length is slightly more than four times the width. Appendages of deutonymph rather similar to those of the protonymph, but more leg-like in structure, for several segments can be distinguished; two clusters of denticles are present on thesc appendages. The four pairs of semicircular structures on the rentral surface are present, but much smaller than in the protonymph.

Protonymphs.-The nymphs of $D$. muscardini differ from the adults, not only in shape, but also in important details of structure. The earlier nymphal stage (protonymph) is rather short and wide, the total length of the body being only from slightly more than twice up to a little less than $2 \frac{1}{2}$ times as long as the greatest width; posterior end of the body rounded off. Capitulum of this nymph very short and wide, being twice as wide as long. True legs are not present, being replaced by very short appendages, which chiefly consist of a chitinous plate or epimeron. The inner end of the epimeron is angular, terminating in a sharp point, whilst the onter end is rounded off. Each of the eight epimera bears two tiny but distinct tubercles on its surface; thesc tubcrcles being of equal size and furnished with 3-4 minute but distinct denticles; (fig. 32 is a lateral view of a very young nymph $72 \mu$ in length, showing the position of the tubercles on the epimera). Four pairs of curious epidermal structures are also present nearer the middle of the ventral surface of the body. They are semicircular in shape, the posterior margin is curved and furnished with sharp denticles, 5-6 in number in the case of the anterior ones, but the last bas only four denticles. These semicircular dises could easily be mistaken for the dereloping legs of the next stage, but are not internal in position, but quite superficial, being placed on the ventral surface of the body. 
Presumably the short appendages and discs bearing denticles serre the purpose of fixation and locomotion.

Besides the nymphs described above, specimens of another stage are met with which resemble the adults in almost every respect but are more delicate in appearance (apparently being less strongly chitinised); the dorsal spines on the capituluin are poorly dereloped in these specimens.

Larva very like the earlier nymphal stage. 'The appendages (epimera) are minute, and only three instead of four in number, as in the nymphs. Each epimeron bears a pair of very minute and inconspicuous tubercles furnished with denticles as in the nymphs. Capitulum very wide.

Ooum oval in shape (length $34 \mu$, width $19 \mu_{0}$ ), its cuticle being thin and delicate. Fig. 33, Pl. VII. shows a female with a fully developed orum in situ in the body.

Author's measurements:-

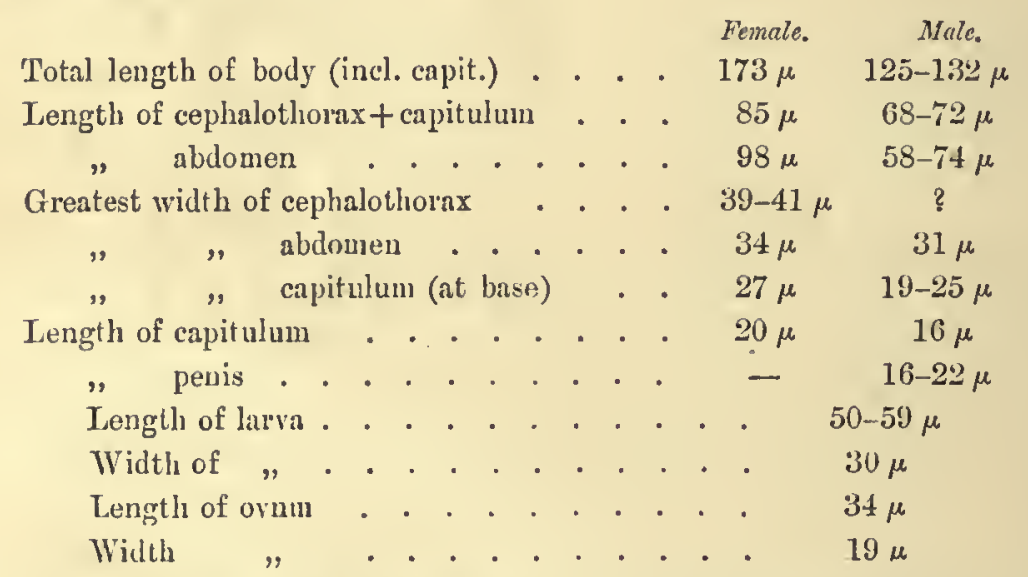

Host: Dormouse (Muscardinus avellanarius). Numerous specimens found in the face and ejelids of the five Dormice examined.

\section{DEMODEX ERMINEA, sp. n.}

(Plate VIII. fig. 34.)

o . A minute but fairly wide species, somewhat resembling $D$. equi in general appearance, but much smaller, and with the spines on the capitulum differently shaped. Body about $3 \frac{1}{3}$ times as long as the width of the cephalothorax. Cephalothorax + capitulum a little longer than abdomen. Capitulum distinctly wider than long; spiues on its dorsal surface well developed and sharply pointerl, much as in 7). arvicolce; the posterior side of the basal end of each spine is rather strongly angular. Male sexual orifice situated above the interval between the 
first and second pairs of legs; the operculum and other genital structures present some resemblance to those of $D$. bovis.

\section{Measurements :-}

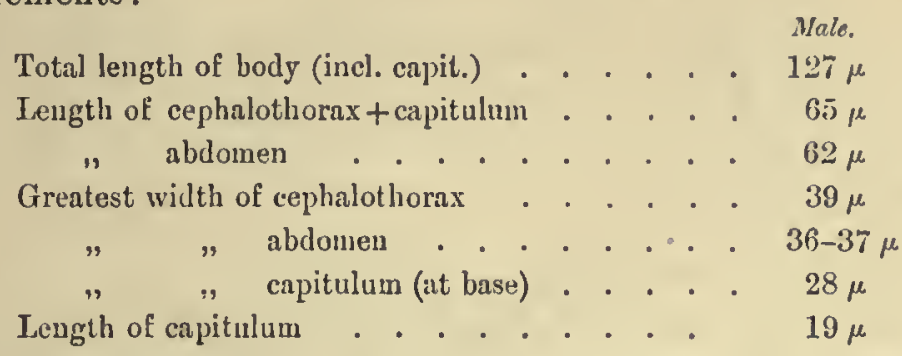

Host : Stoat (Mustela erminea). Two males from a Stuat trapped in the vicinity of Exeter, Oct. 1918.

10. DEMODEX ARVICOLA, Zschokke, 1888.

D. arricole, Zschokke, Schweizer Arch. f. Tierheills. 1888, vol. xxx. p. 69.

(Plate IX. fig. 37.)

q. This is the typical form and apparently sometimes reaches a slightly greater length than the variety musculi. ('/schokke's specimens evidently were much larger.) Body from less than $4 \frac{1}{2}$ up to almost six times as long as the width of the cephalothorax. Abdomen longer than cephalothorax + capitulum. Capitulum about as wide as long. Penultimate segment of palp strongly salient and pointed laterally. Dorsal spines on capitulum well developed and pointed, as in the var. muscutli.

Author's measurements :-

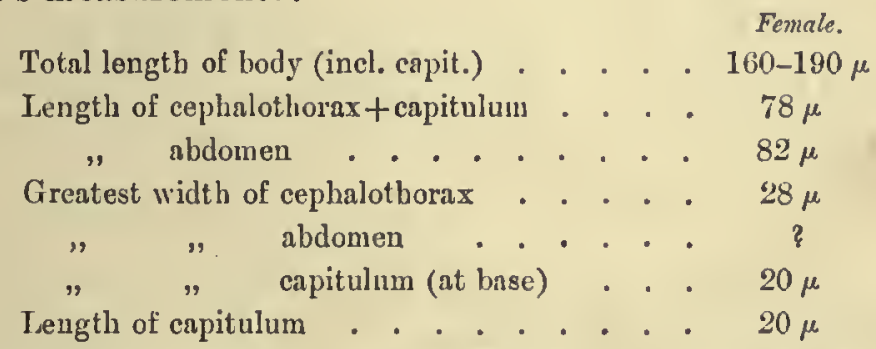

Zschokke's measurements of this Demodex are as follows (according to Gmeiner) :-

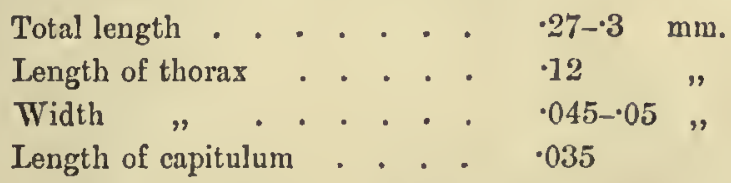

Host: Fiold Fole (Microtus [Arvicola] agrestis). Two adult female specimens of the mite from an example of this mammal caught near Eton. 
DEMODEX ARVICOL E VAR. MUSCULI, Ondemans, 1898.

(Plate XI. figs. $38-40$; Plate X. figs. $41,42$. )

D. folliculorum var. musculi, Oudomans, Tijdschr. f. Ent. 1897, rol xl. p. 269.

D. musculi, Oudemans, Ent. Ber. Ned. Ver. 1909, vol. ii. no. 47, pp. 318 \& 319.

D. musculi, Hirst, Ann. Mag. Nat. Hist. (ser. 8) vol. xx. 1917, pp. 233 \& 234, text-fig. 2, pl, ix. fig. 2.

․ The Demodex occurring in the Mouse is a minute species. The proportions of the body vary considerably in female specimens, some being rather short and wide, others more elongated and much more slender; even the scphalothorax differs greatly in width (see figs. 39, 40). Body from a little more than four up to about six times as long as the width of the cephalothorax. Abdomen sometimes only a little longer than cephalothorax + capitulum, but it may reach up to $1 \frac{1}{2}$ times as long; it is sometimes elongate sac-shaped, being widest some distance before the rounded postcrior end, but the sides may be practically straight.

on. Body from a little more than 4 up to about $4 \frac{1}{2}$ times the cephalothoracic width. Abdomen a little longer than combined length of cephalothorax and capitulum, its posterior end may be rounded off or pointed. Capitulum usually wider than long (at base); distal end with the outer angles strongly salient and pointed laterally; spines well developed and sharply pointed as in the female. Male sexual orifice situated above the epimera of the second legs. Penis shaped as figured; operculum of opening conical in shape.

Deutonymph reaching a comparatively large sizc, its body up to about $7 \frac{1}{2}$ times the width of the cephalothorax; ventral tubercles, etc., of the usual type.

Author's measurements :-

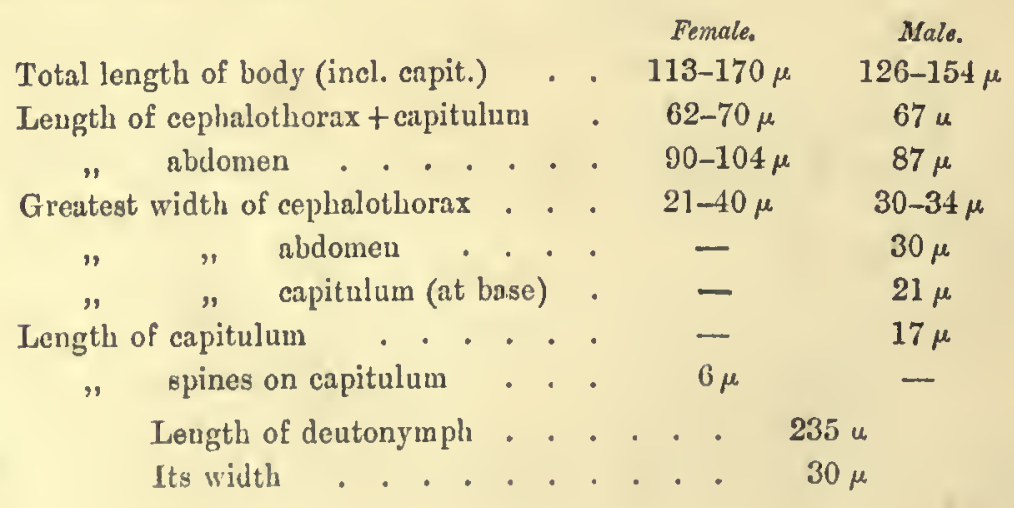


Oudemans gives the following measurements for this variety:-

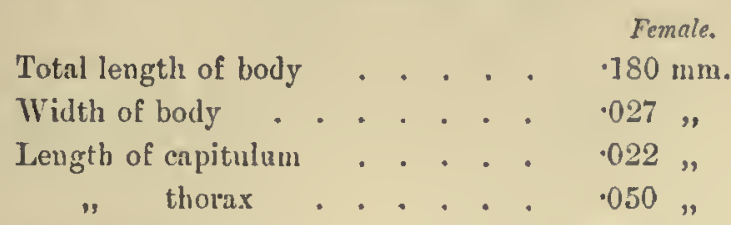

Host: House Mouse (Mus musculus). A number of specimens from tame mice.

DEMODEX ARVICOLE VAR. APODEMI, Hirst, 1918.

Demodex apodemi, Hirst, Ann. Mirg. Nat. Hist. (ser. 9) vol. ii. 1918, p. 145.

(Plate X. figs. 43-45.)

․ A very minute but fairly elongated species. Body about $4 \frac{1}{2}$ times as long as the greatest width of the cephalothorax. Abdomen a little less than twice the combined length of cephalothorax and capitulum. Capitulum (at base) wider than its length. Spines on dorsal surface of capitulum well developed, being pointed at the end, as in var. musculi, etc.

8. Body from a little more than four up to about five times as long as width of cephalothorax. Abdomen about as long as cephalothorax + capitulum. Capitulum when fully extended, about as long as wide. Male sexual aperture above interval between second and third pairs of legs. Penis fairly long and slender.

Author's measurements :-

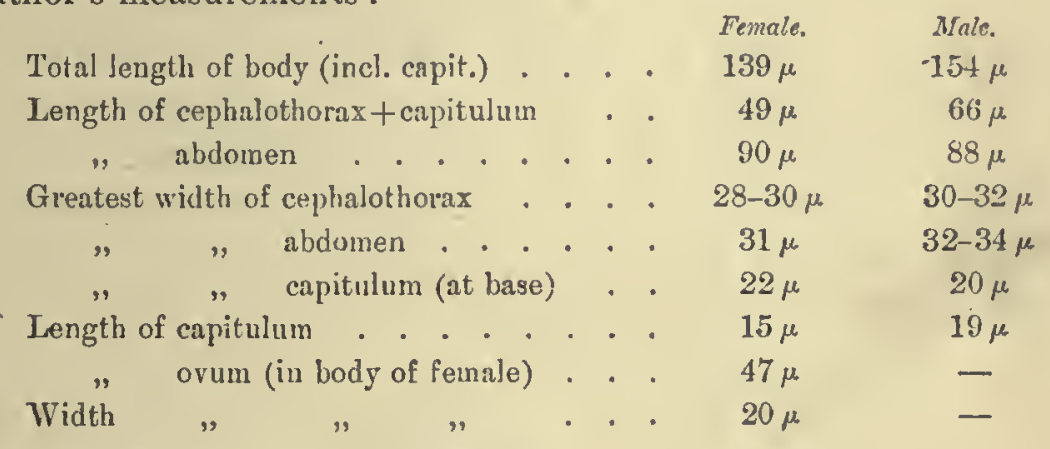

Host : Field Mouse (Apodemus syluaticus).

\section{DEMIODEX ARVICOLA}

(Plate XI. figs. 49, 50.)

9. Proportions very much the same as in slender specimens of rar. musculi. Body about $5 \frac{1}{3}-5 \frac{3}{4}$ as long as the cephalothoracic width. Abdomen a little longer than cephalothorax + capitulum. Capitulum fairly elongated, being about as long as wide; spines on its dorsal surface much like those of var. musculi in shape. 
* Body abont $4 \frac{2}{3}$ times as long as widtl of cephalothorax. Abdomen ouly slightly longer than cephalothorax +capitulum. Spines on capitulum seemingly more slender than in male of var. musculi. Male sexual orifice placed above the second pair of legs.

Author's measurements :-

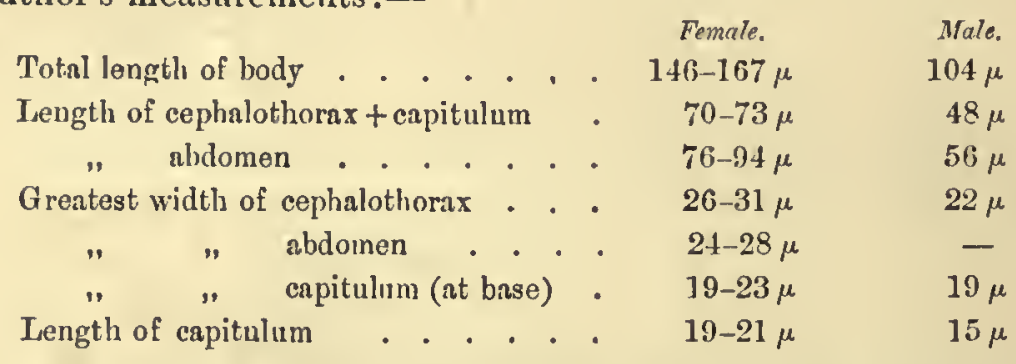

Host: Several female examples and a single malo collected hy the author froin specimens of the Bank Vole (Evotomys glareolus britannicus), trapped at Teignmouth and near Exeter, Devonshire, September 1918.

11. DEMODEX CUNICULI, Pfeiffer, 1903.

Acarıs folliculorum cuniculi, Pfeiffer, Berlin tieriirztl. Wochenschr. 1903, pp. 155 $\& 156$.

\section{(Plate XII. fig. 51.)}

\%. Body abont four times as long as the width of the cephalothorax. Abdomen a little longer than cephalotlorax+capitulum. Capitulum about as wide as, or only slightly wider than long; spines ou its dorsal surface smaller than in male of $I$. musculi. Male sexual opening rather far back, being situated between the second pair of tiny tubercles on the dorsal surface above the (ventral) transverse groove between the second and third legs. Penis fairly long and slender.

A uthor's measurements :-

Male.

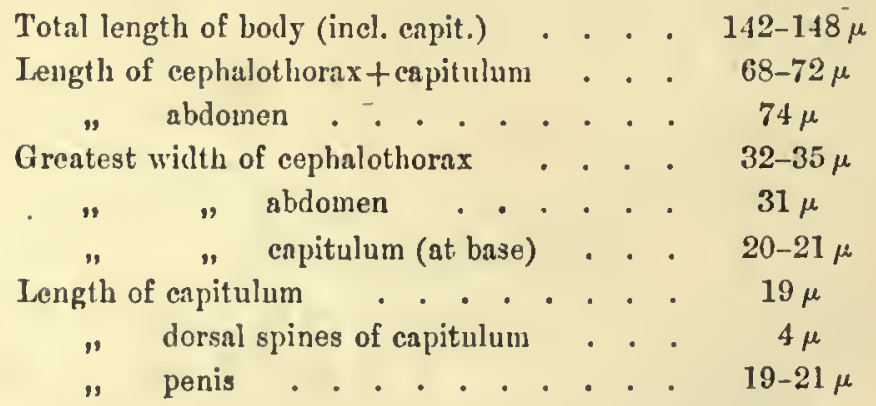

Host: Two adult males from tame rabbits (Oryclolagus cuniculus).

Notr. - Possibly only a variety of $D$. arvicol ce. 


\section{DEMODEX RATTI, Hahn.}

\section{(Plate XI, figs. 46, 47.)}

․ This species is long and slender, being about seven and a half to eight and a half times as long as the width of the cepbalothorax. Capitulum narrow, being longer than wide. Cephalothorax also characteristically narrow and much shorter than the abdomen; the latter is wider, but fairly long and vermiform. The two spines on the dorsal surface of the capitulum are well developed, being longer than in D. arvicole ; they are pointed at the end.

Author's measurements :-

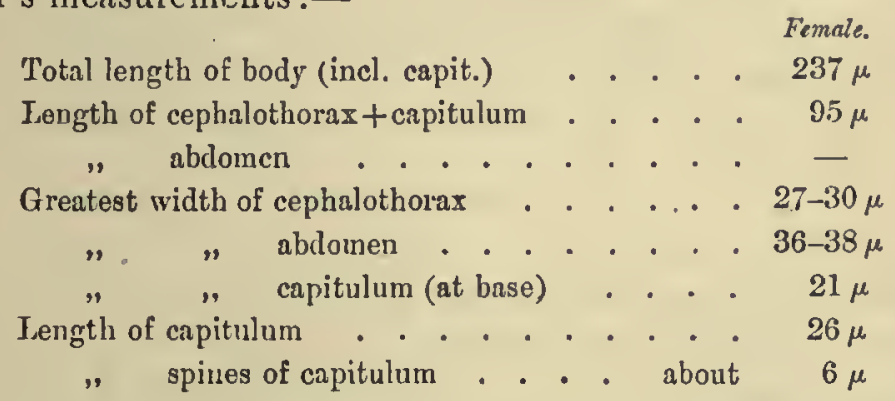

Host : I have examiued three adult female specimens collected by Leslie Linzell from a Brown Rat (Rattus norveyicus). M.I. Linzell informs me that the parasites were very sbuudaut in the skin of this rat.

\section{DEMODEX SORICINUS, Hirst, 1918.}

D. soricinus, Hirst, Ann. Mag. Nat. Hist. (ser.9) ii. 1918, p. 145.

(Plate XI. fig. 48.)

f. A small species, the cephalothorax being fairly wide. Body a little more than three times the width of the cephalothorax. Abdomen pointed posteriorly and somewhat longer than cephalothorax + capitulum. Capitulum wider than long. ('The spines on the capitulum cannot ise seen in the unique specimen, which lies ventral side uppermost.)

Female.

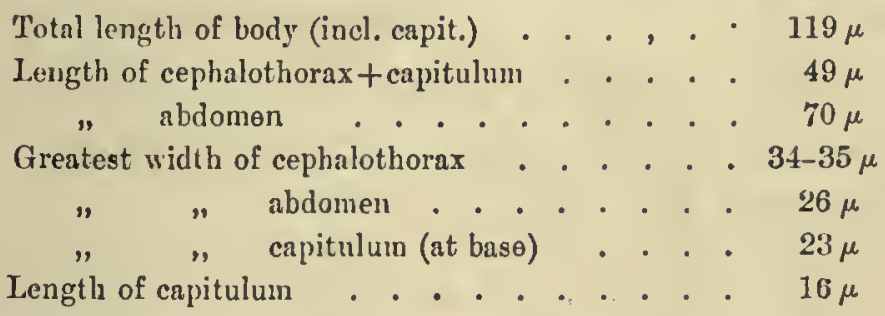

IIost: Common Shrew (Sorex araneus castaneus).

The following Demodex was described as a new species but is almost certainly the same as $D$. soricinus. 
13 a. DEMODEX NANUS, Hirst, 1918.

Ann. Mag. Nat. Hist. (ser. 9) rol. ii. 1918, p. 146.

\%. A minute but fairly wide form much like that present in Sorex araneus castaneus. Length about $3 \frac{1}{2}$ times the width of the cephalothorax. Abdomen usually considerably shorter than combined length of cephalothorax and capitulum, but in one specimen it is longer. Capitulum usually much wider than long; the spines on its surface apparently obsolete or absent.

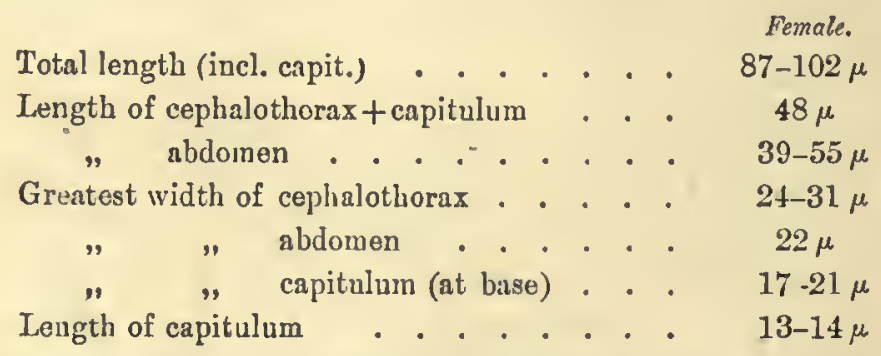

Host: Black Rat (Rattus rattus) and Brown Rat (Rattus norvegicus). Several specimens collected from freshly killed rats by the author.

Noтv,-Hahn has already described a species of Demodex ( $D$. ratti) from a house rat said to be Mus rattus. I have not been able to consult his original description, which is referred to by Gmeiner. The latter says that the species is similar to that of the dog. From this one would infer that it was an elongated form of comparatively considerable size similar to that found in Rattus norvegicus. It is probable, indeed, that the rat from which Hahn's specimens were taken was really Rattus norvegicus, the Brown or Norwegin Rat (syn. Rattus decumanus). I have only found specimens of the short form described above in Black Rats, but both this form and the elongated form described under the name D. ratti (see p. 37) are found in the Brown Rat, which thus certainly harbours two distinct species. It is, of course, possible that both forms also occur in the Black Rat.

The following species or varieties have not been examined by the author:-

\section{DEMODEX CAPRA, Railliet, 1895.}

D. folliculorum var. capra, Railliet, Zool. Méd. Agric. 2nd Edit. 1895, p. 638.

According to Railliet the cephalothorax+capitulum of D. caprce together are almost equal to half the total length of the body. $\mathrm{He}$ gives the following measurements:-

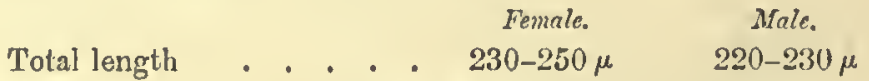

$$
\begin{aligned}
& \text { Width . . . . . . 60-65 } \mu \quad 50-55 \mu \\
& \text { Ova ellipsoid (length } 68-80 \text {, width } 32-45 \mu \text { ). }
\end{aligned}
$$

Host: The Goat (Capra hircus). 


\section{DEMODEX CERVI, Prietsch.}

Host: Sambar Deer (Cervus sp..). Loc.?

16. DEMODEX PHYLLOSTOMATIS, Leydig, 1859.

D. phyllostomatis, Leydig, Arch. f. Naturg. 1859, Jahrg. i. 25. p. 345, pl. 13. figs. $7-10$.

Judging from Leydig's description and figures, this Demodex is a short and wide species, very like $D$. bovis in appearance and proportions, the posterior end of the body also pointed as in that species. The abdomen is not longer than the cephalothorax. Pseudosegments of the body well defined, the aunulations being thick and sharp. Eggrs oval in shape.

Host: A Bat (Phyllostomu hastatum), Surinam.

\section{BIBLIOGRAPHY.}

A list of over two hundred and thirty papers dealing with Demodex (chiefly with tho form occurring in the dog and the disense with which it is associated) has been compiled by the author, and a complete list wonld be much longer. Owing to the great increase in the cost of printing and paper it has been necessary to omit this list from the present pamphlet. The more important systematic works on the subject are mentioned in the short history of the group given on page 9. A. list of a bundred papers will be found at the end of Gmeiner's paper (Arch. Dermat. Sypb. Wien, vol. xcii., 1908, and Zeitschr. f. Tiermed. Jena, vol. xiii., 1009). Another good list is that given by Huber in his 'Bibliographie der klinischen Entomologie' (Hexapoden, Acarinen), Jena Heft 2, 1849, pp. 1-8. Numerous papers are, however, omitted from these two lists. 


\section{IN DEX.}

Acarus folliculorim (= Demodex folliculorum), 19.

Acne rosacea, 1.

Affinities of group, 10 .

Ape, Demodex of, 19.

Aporlemus sylvaticus, Demorlex of, 26, 35 .

Arvicola ugrestis, Demodex of, 33.

Bank Vole, Demodex of, 36.

Barbary Ape, Demodex of, 19.

Bat, Demodex of, 39.

Black Rat, Demodex of, 38.

Blepharitis, 2.

Bos taurus, Demodex of, 29.

Brown Rat, Demodex of, 37, 38.

Cancer, 2.

Canis familiaris, Demodex of, 24 .

Capitulum, 12.

Capra hircus, Demorlex of, 38.

Cat, Demodex of, 26.

Cattle, Demodex of, 29.

Cervus sp., Demodex of, 39.

Cheletidx, 11.

Cheliceræ, 15.

Deer, Demorlex of, 39.

Demodectic mange, of cat, 6 ; of cattle, 7 ; of dog, 3 ; of guat, 9 ; of horse, 6 ; of pig, 8.

Denodex arvicola, 33.

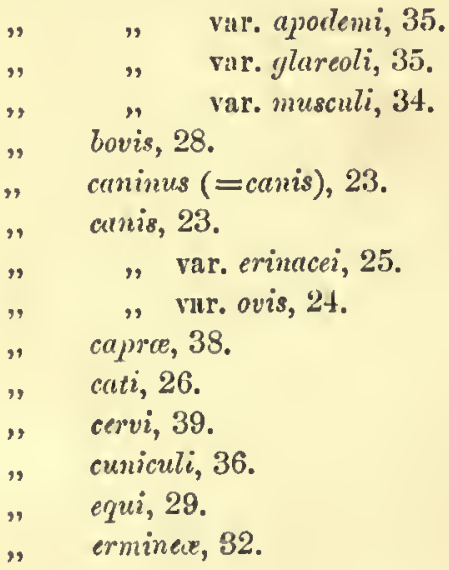

Demodex folliculomm, 19; folliculorum, val. suis (=phylloides), 27 ; effects of parnsitism of, 1 . hominis ( $=$ folliculorum), 19.

" longior, 25.

" muscardini, 30.

" nanus, 38.

" phylloiiles, 27.

" phyllostomatis, 39.

" ratti, 37.

" soricinus, 3i.

" suis, folliculormm var. (=phylloides), 27.

Distribution, 18.

Dog, Demodex of, 24.

Dormouse, Demodex of, 32.

Entozoon folliculorum (= Demodex folliculorum), 19.

Equus caballus, Demodex of, 30.

Frinaceus europaus, Demodew of, 25.

Evotomys glareolus britumicus, Demodex of, 36.

F'elis domestica, Demodex of, 26.

Female sexual opening, 17.

Field Mouse, Demodex of, 26, 35.

Follicular mange, 3.

Fox, Demodex of, 19.

Goat, Demodex of, 38 :

Habits, 12.

Harpyrynchus, 11.

Hedgehog, Demodex of, 25.

Horse, Demodex of, 30.

Hosts, list of, 18.

Impetiginous eruption, 2.

Legs, 15 .

Leprosy, 2.

Lichen spinulosus, 2.

Macrogaster platypus (=Demodex folliculorum), 19.

Male sexual opening, 16 .

Man, Demodex of, 22.

Mange (sce Demodectic). 
Marmot, Demodex of, 19.

Maxillx, 15.

Microtus agrestis, Demodex of, 33.

Ilolluscun contagiostum, 1.

Muuse, Demodex of, 35.

Mouth-parts, 15.

Muscrerlinus rvellanarius, Demodex of, 32.

AKus musculus, Demodex of, 35.

Mrustela erminea, Democlex of, 33.

Myobia, 11.

Origin of group, 10.

Oigctolagres cuniculus, Democlex of, 36.

Ovis aries, Demodex of 24.

Palpi, 12.

Penis, 16.

Mhyllustoma hastatum, Demorlex of, 39.

Pig, Demodex of, 27.

Pigmentation of skin, 1 .

P'sorergates, 11.

Rabbit, Demodex of, 36.

Rats, Demodex of, 37, 38.

liattus norvegicus, Demodex of, 37, 38; $R$. rattus, Demodex of, 38.
Red mange, 3 .

Respiratory вystem, 11, 12, 15.

Sarcoptes, 11.

Sarcoptidæ, 12.

Scalp disease, 2.

Sheop, Demodex of, 24.

Shrew, Demodex of, 37.

Simonea folliculorum (=Demodex folliculorum), 19.

Sorex urrneus castaneus, Democlex of, 37.

Staphylococcus, 3, 5.

Steatozoon folliculorum ( $=$ Demodex folliculorum), 19.

Stigmata, 12, 15.

Stoat, Demodex of, 33.

Sus scrofa, Demodex of, 27.

Taxonomy, 17.

Tinea versicolor, 1.

Trachex, 11, 15.

Treatment of disease induced by Demodex, in man, 2 ; in $\operatorname{dog}, 5$; in horse, 7 ; in cattle, 8 ; in gont, 9 .

Voles, Demodex of, 33, 36. 


\section{EXPLANATION OF PLA'TES.}

Nоте.-The figures on these plates are not drawn on the same scale-for instance, that of $D$. boris (Pl. I. fig. 6 ) is more greatly magnified than tho others on Plate I.

\section{Plate I.}

Fig. 1. Demodex folliculorum, G. Simon, 우 Ventral view. $\times 345$.

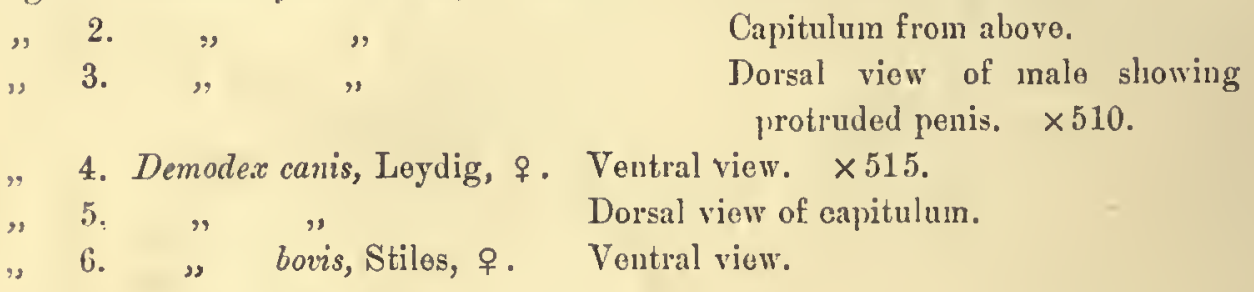

\section{Plate II.}

Fig. 7. Demode $x$ bovis. Dorsal view of male slowing protruded penis. $\quad \times 530$.

"8. " " Lateral view of male. $\times 525$.

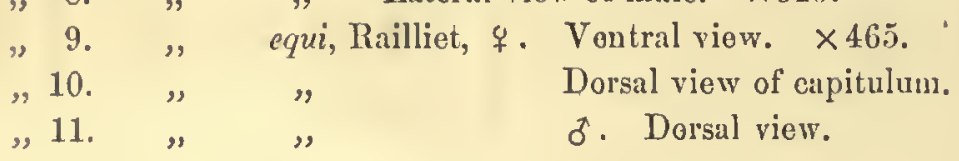

\section{Plate III.}

Fig. 12. Demodex folliculorum. Elongated larval form from below. $\times 419$.

" $12 a \& b$. Appendages of larval form.

" 13. Demodex canis var. ovis, Raill. + . Ventral view. $\times 665$.

"14. " folliculorum. Elongated nymph. $\times 439$.

"14a\&b., " Appendages of nymph.

"15. " $"$ Short form of male. $\times 694$.

"15 a. " - , Penis greatly onlarged.

\section{Plate IV:}

lig. 16. Demodex canis var. ovis. Dorsal viow of capitulum.

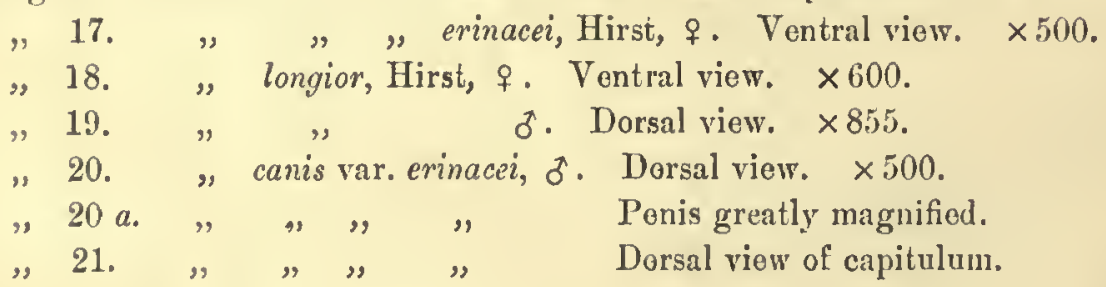




\section{Plate V.}

Fig. 22. Demodex plylloides, Csokor, \&. Ventral view. $\times 517$.

"23. " cati, Mégnin, $\delta$. Dorsal view. $\times 847$.

"23a. " " Penis.

"24. " phylloides, Csokor, $\subsetneq$. Dorsal view. $\times 526$.

"25. " bovis. Larva.

"26. " " Ponis.

"26a. End of penis of $D$. hovis as it appears when protruding from sexual orifice.

" $26 b$. Tip. of penis of the same species greatly enlarged.

\section{Plate VI.}

Fig. 27. Demodex muscardini, Hirst. Young nymph.
"27 a. , "
One of the epidermal seales of this nymph, greatly enlarged.
" 27 b. " " $\quad$ End of palp of nympl much onlarged.
"28. " $"$ Ovum. $\times 1147$.
"29. " " Larva. $\times 2100$.
"30. Large nymphal form of $D$. buris showing eompletely formed adult inside. $\times 485$.
" 30 a. One of the appendages of this nymph greatly enlarged.

\section{Plate VII.}

Fig. 31. Demodex muscardini, ㅇ․ Ventral view. $\times 835$.
"32. " " "
Lateral view of nymph. $\times 1555$.
" $33 . \quad$ "
ㅇ. Lateral viow slowing an egg in situ. $\times 888$.

\section{Plate VIII.}

Fig. 34. Demodex erminece, sp. n., ð. Dorsal view. $\times 984$.

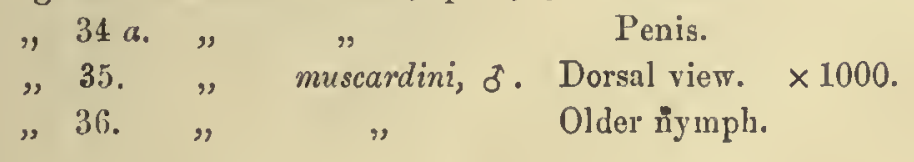

\section{Plate IX.}

Fig. 37. Demodex arvicolce, Zschokke, ㅇ․ Ventral view. $\times 800$.

\begin{tabular}{|c|c|c|c|c|c|}
\hline , 38. & $"$ & " & var. musculi & Oudnss. & $\begin{array}{l}\text { Elongated nymphal form. } \\
\times 765 \text {. }\end{array}$ \\
\hline $38 a \& b$ & " & $"$ & $"$ & & $\begin{array}{l}\text { Lateral platelets of this nympl } \\
\text { much enlarged. }\end{array}$ \\
\hline $39 \& 40$ & $"$ & ", & ", & $q$. & $\begin{array}{l}\text { Ventral views showing vari- } \\
\text { ation in shape of body. }\end{array}$ \\
\hline
\end{tabular}




\section{Plate X.}

Fig. 41. Demodea arvicolo var. musculi. Dorsal view of capitulum.

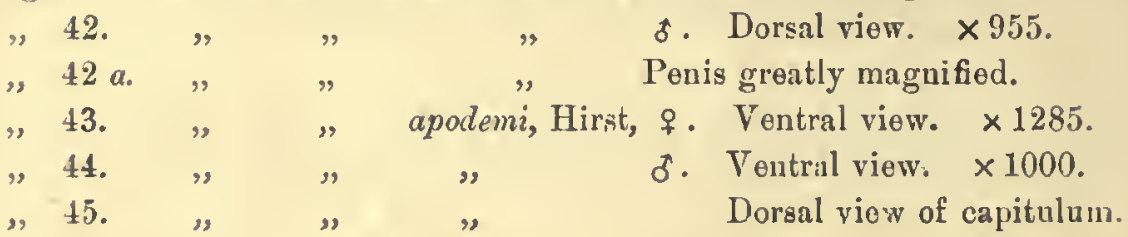

\section{Plate XI.}

Fig. 46. Demodex ratti, Hahn, + . Ventral view. $\times 680$.

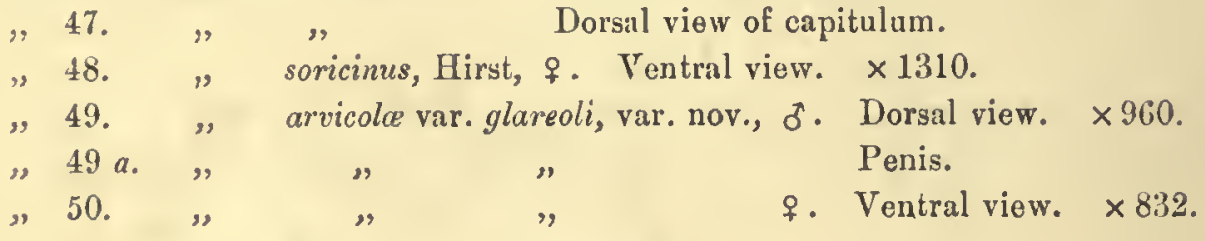

\section{Plate XII.}

Fig. 51. Dernodex cuniculi, Pfeiffer, dे. Dorsal view. $\times 925$.

" 51 a. " " Penis.

" 52. A Choletid Mite, Psorergates musculinus, Michaol. Dorsal viow showing male sexual aperture, penis, etc.

\section{Plate XIII.}

Fig. 53. A Cheletid Mite, Myobia sp. Dorsal view showing male sexual opening, penis, etc. 
ACARI BRIT. MUS. (NAT HIST.)

I. DEMODEX

PL. 1.

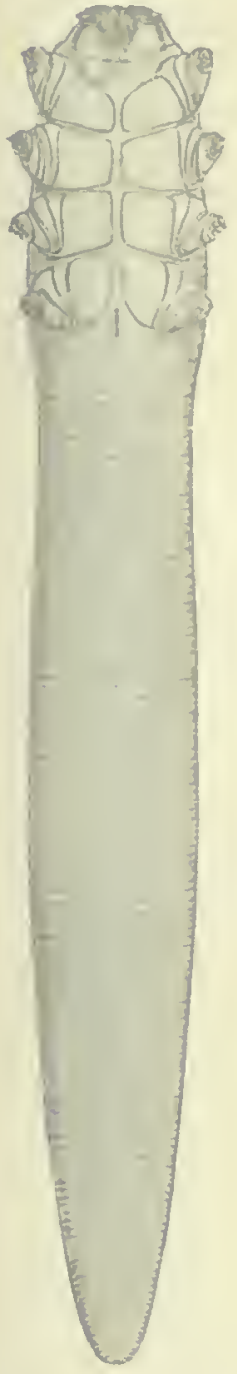

1

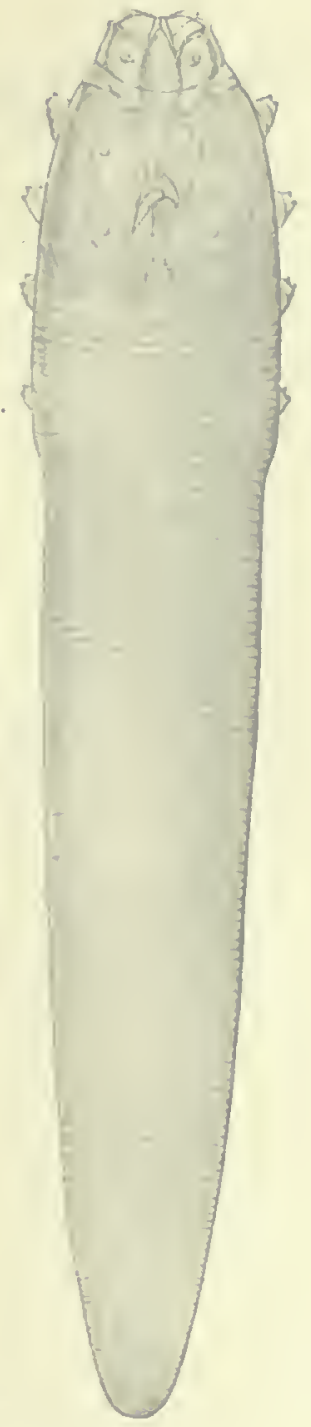

3

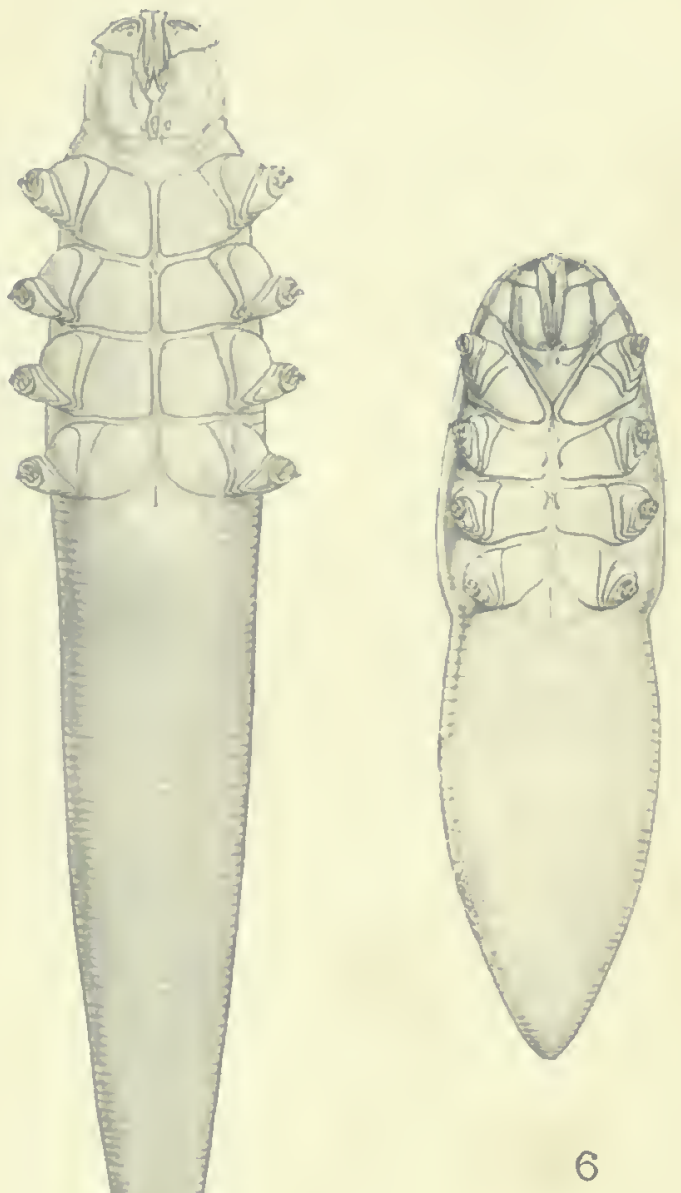

4

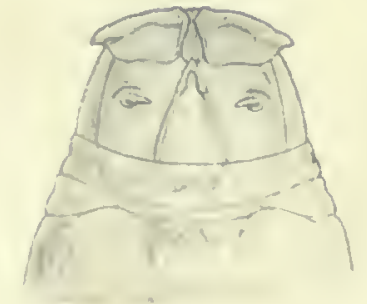





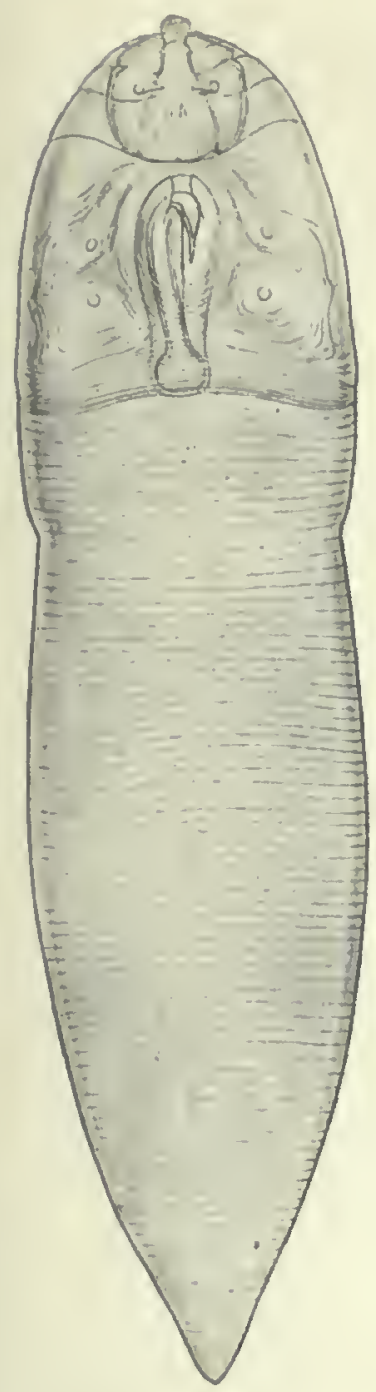

7

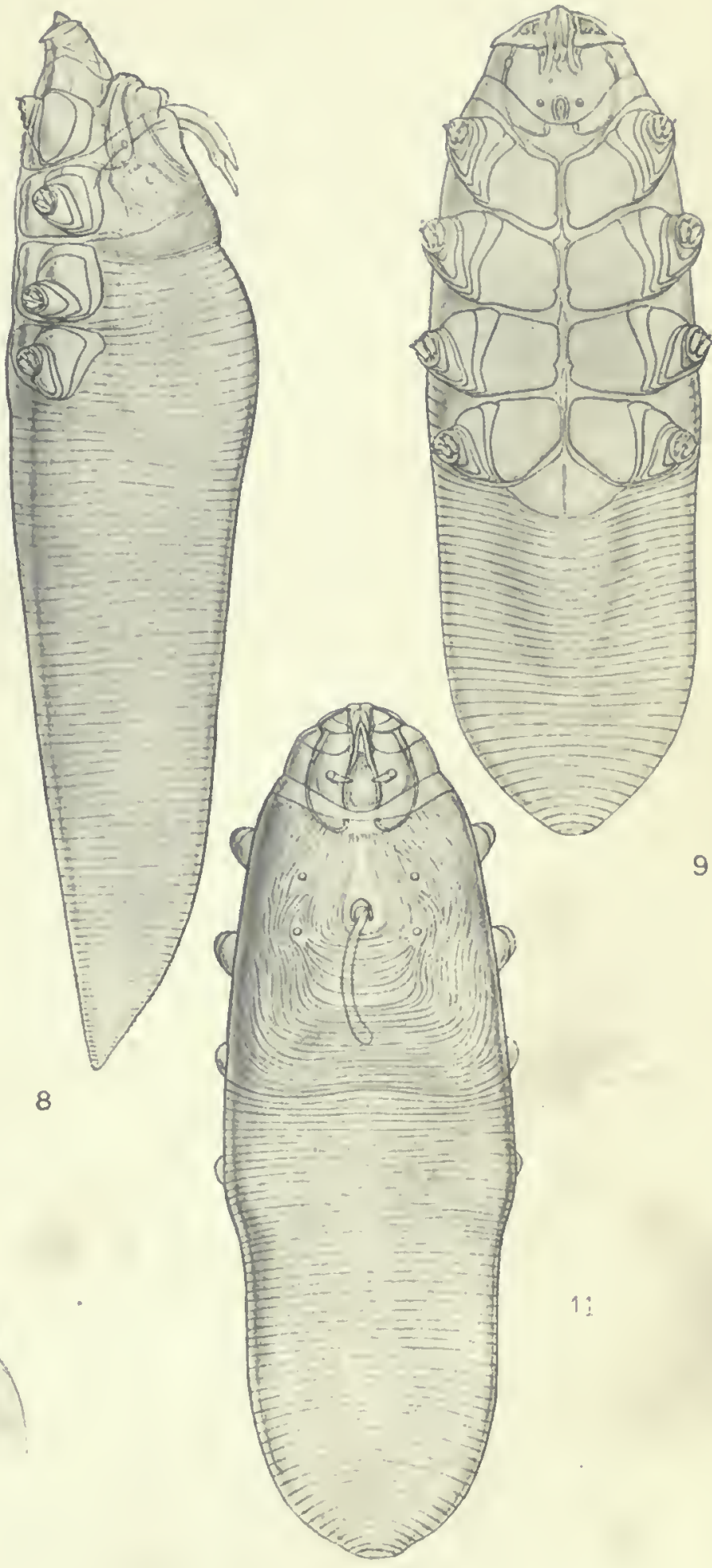





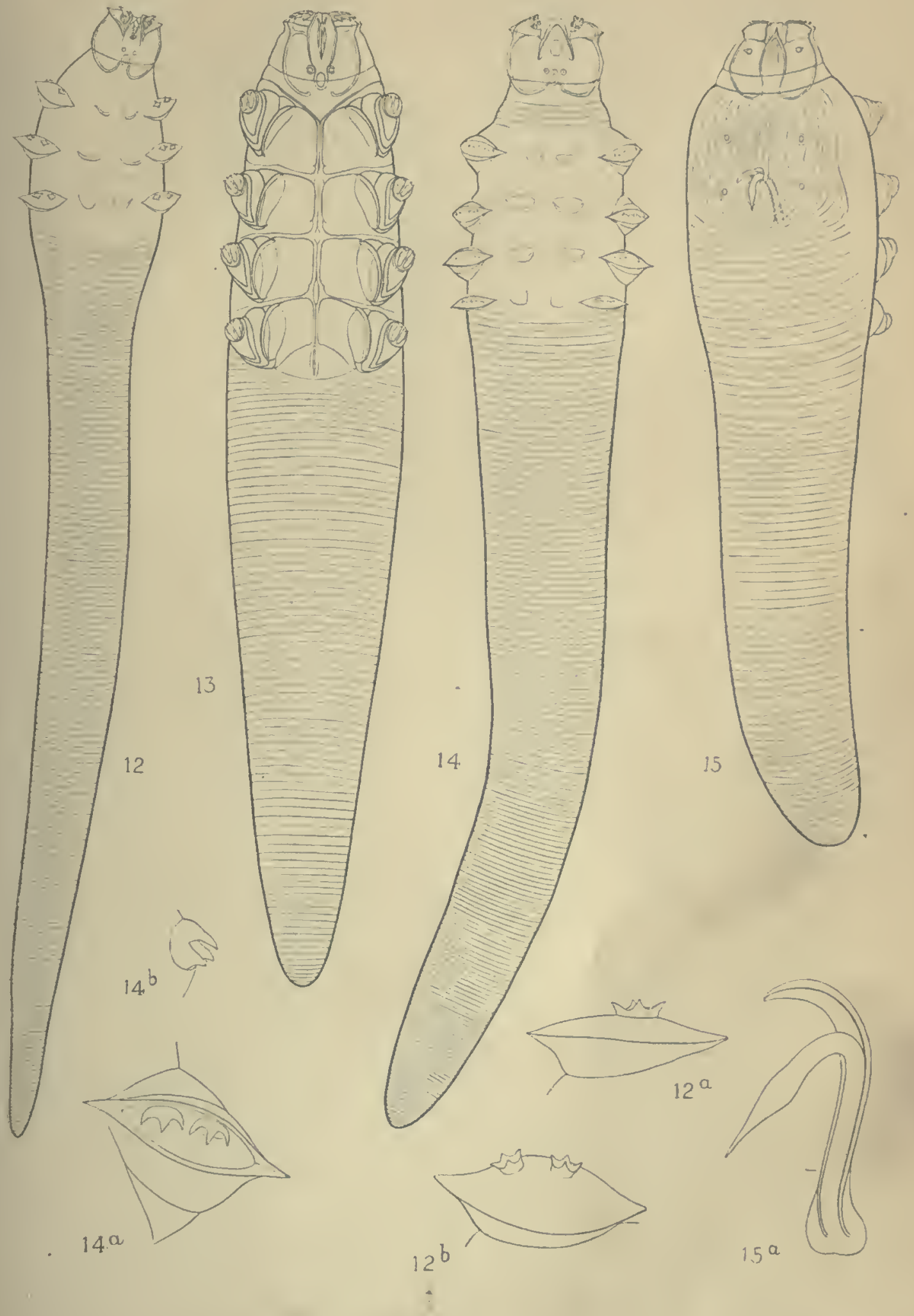




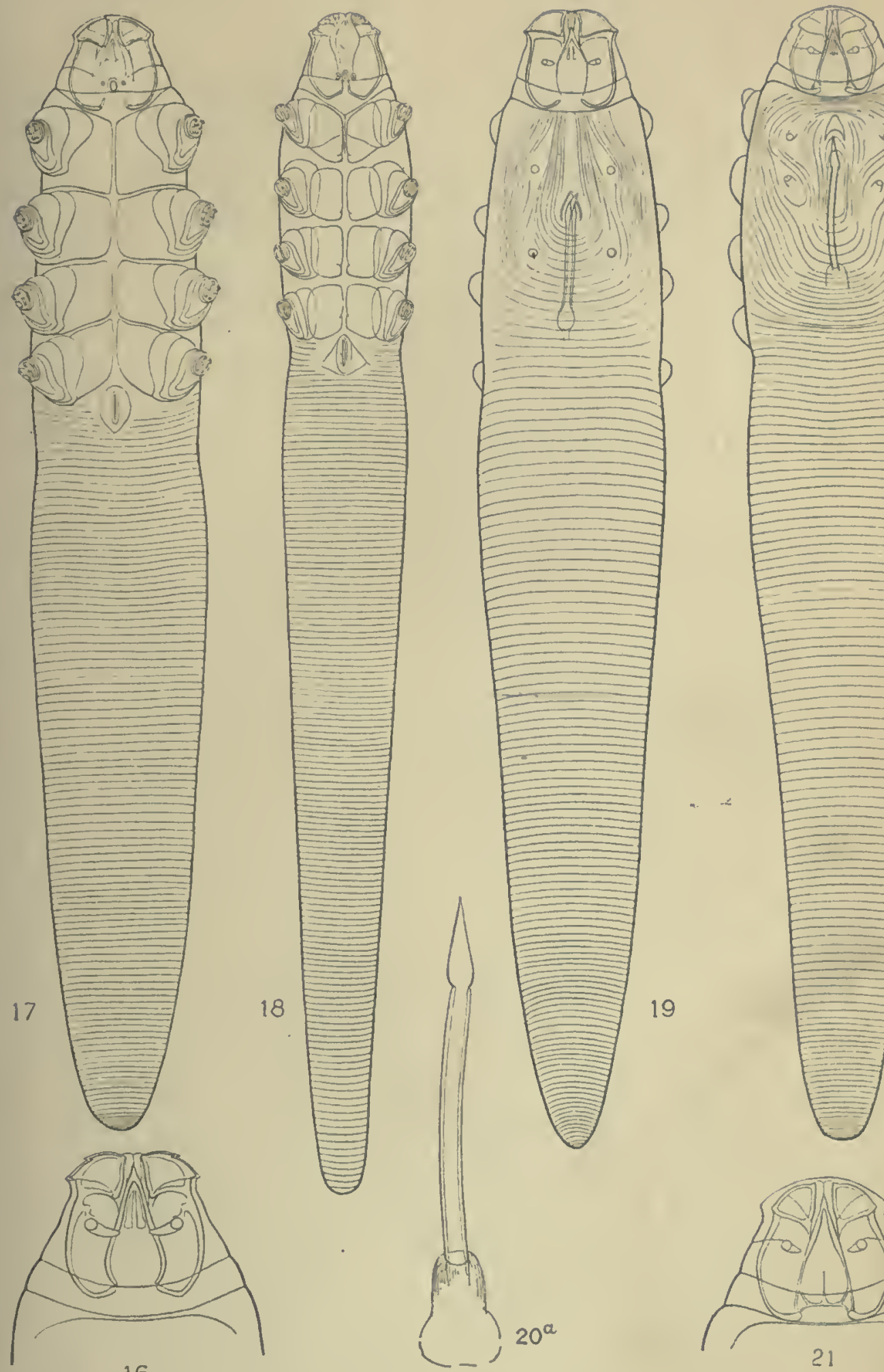

18

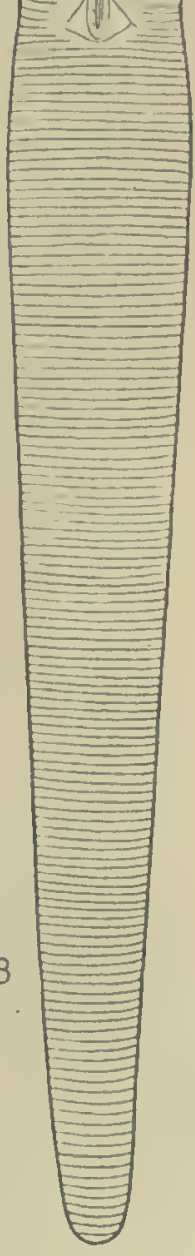

16
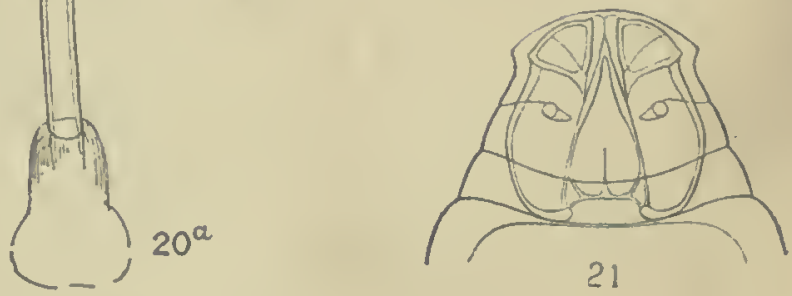

F. Higheg, del. 


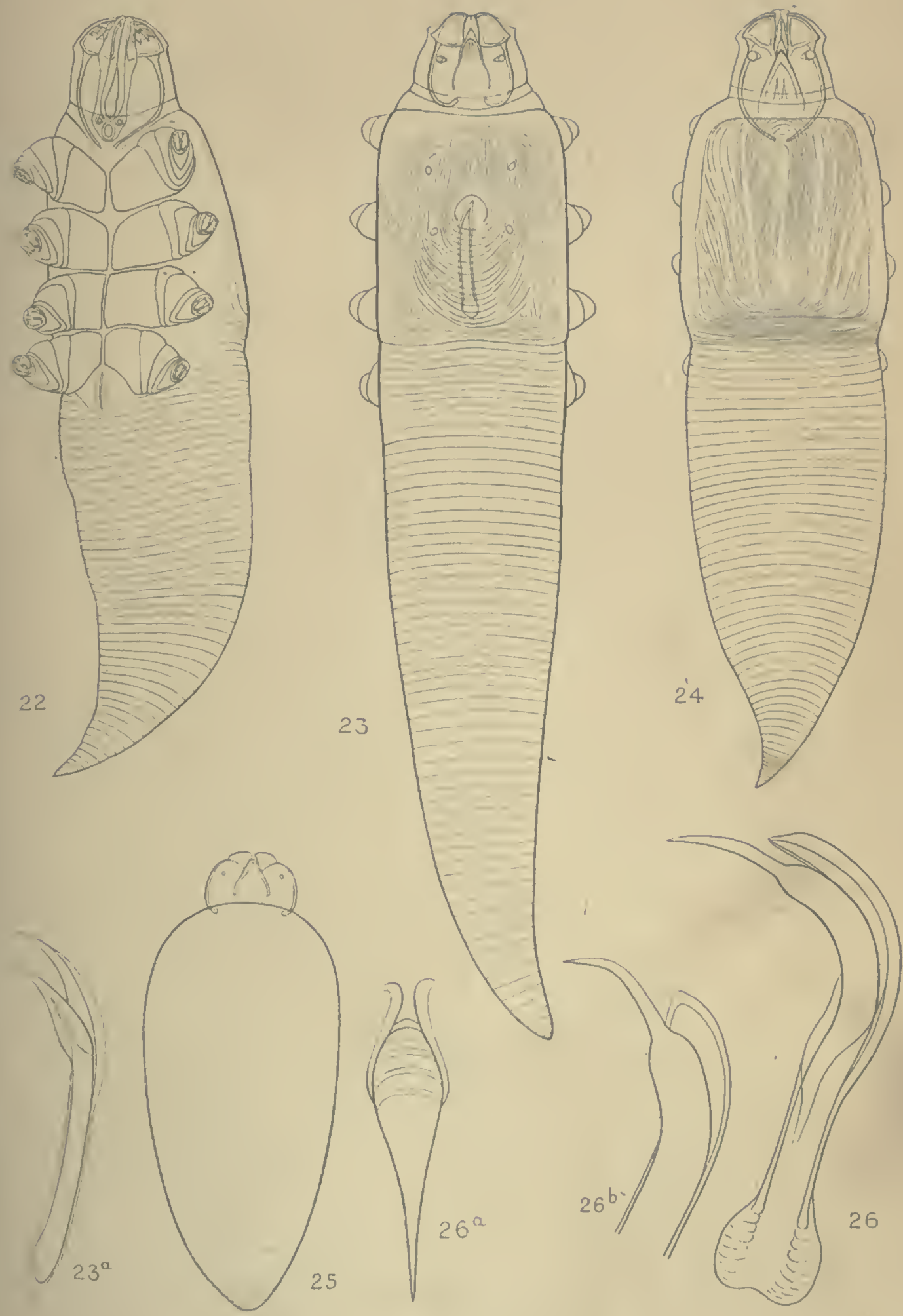



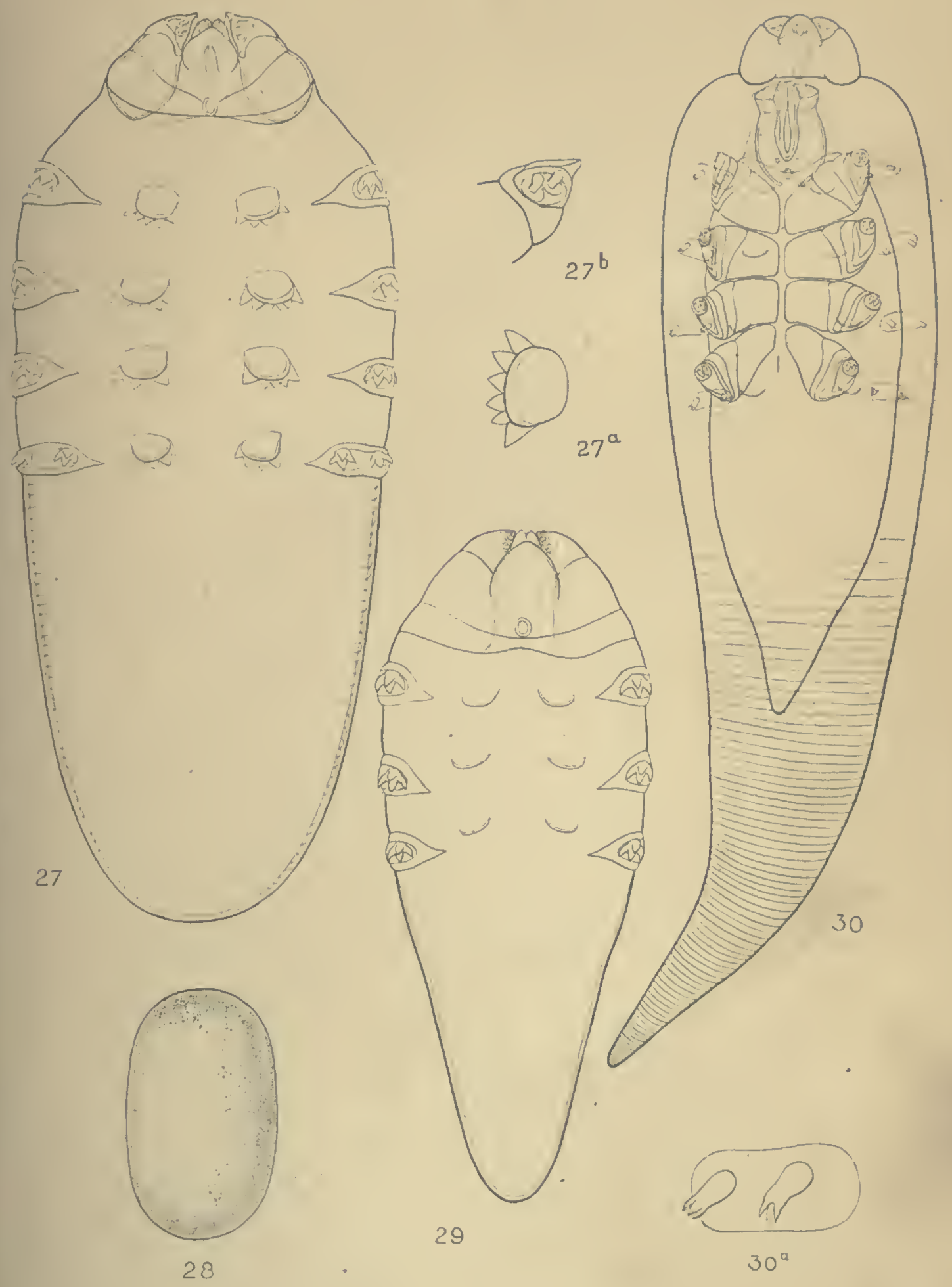



ACARI Brit. Mus. (NAT. Hist.)

I. DEMODEX.

PL. VII.
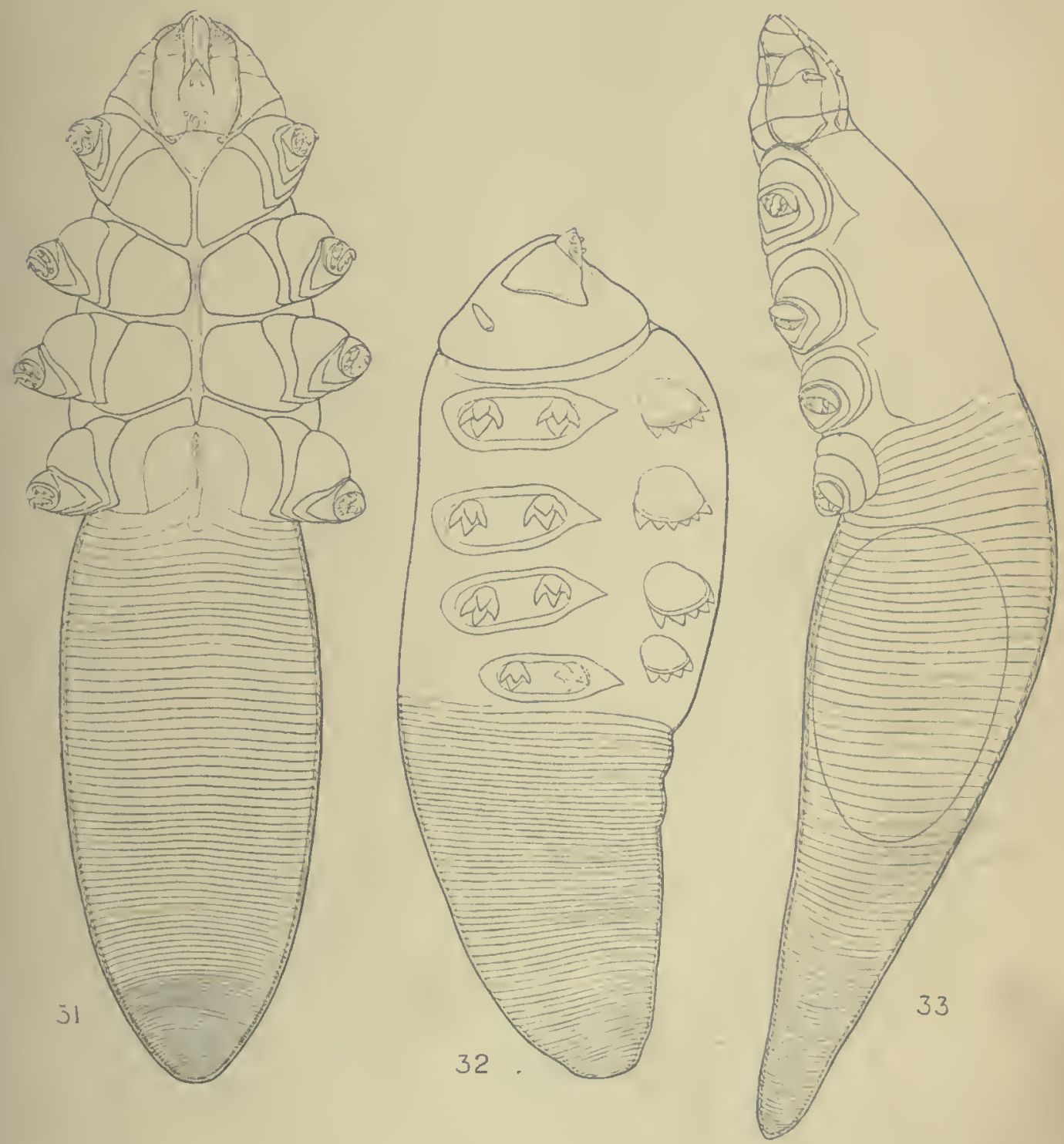



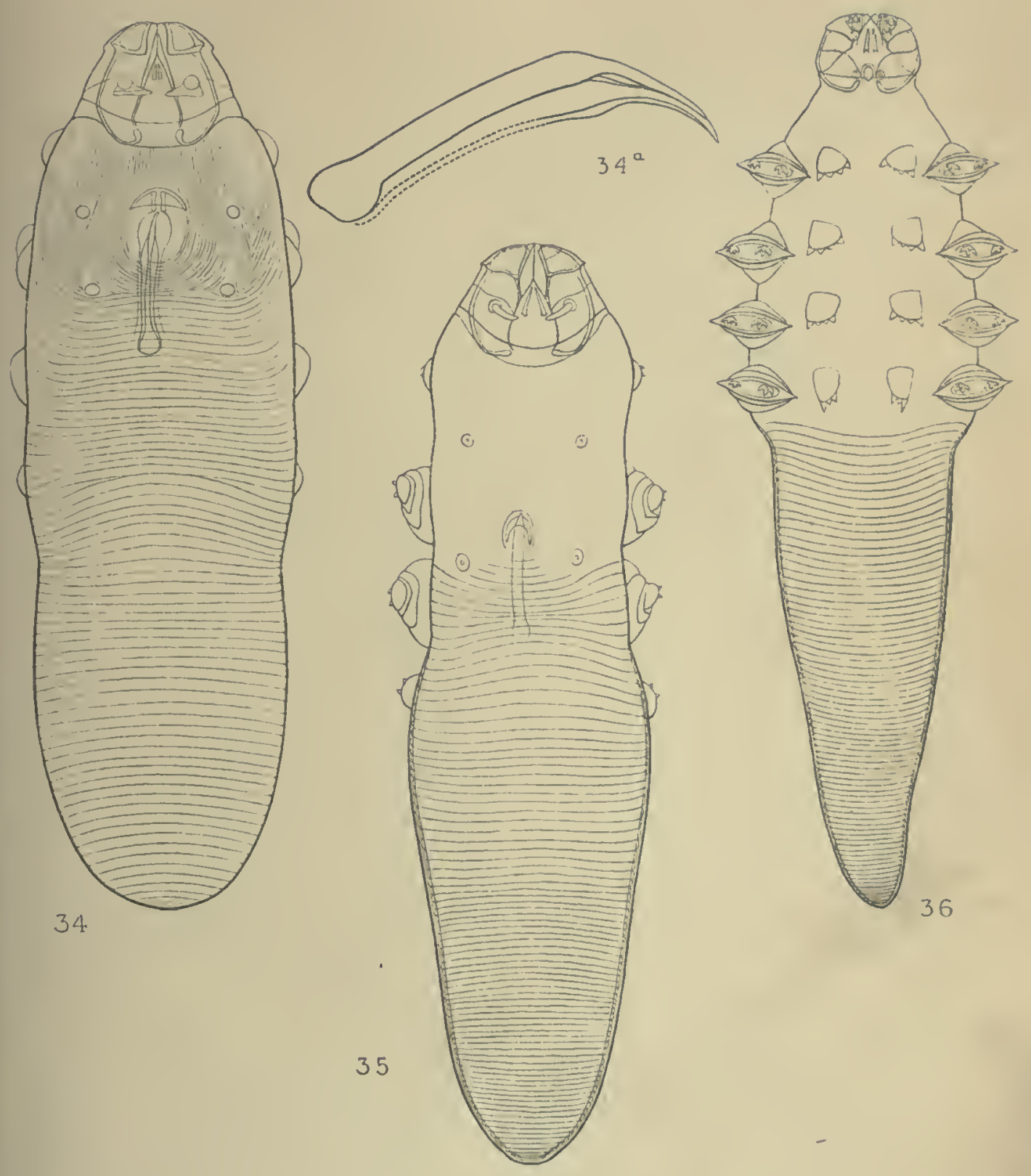




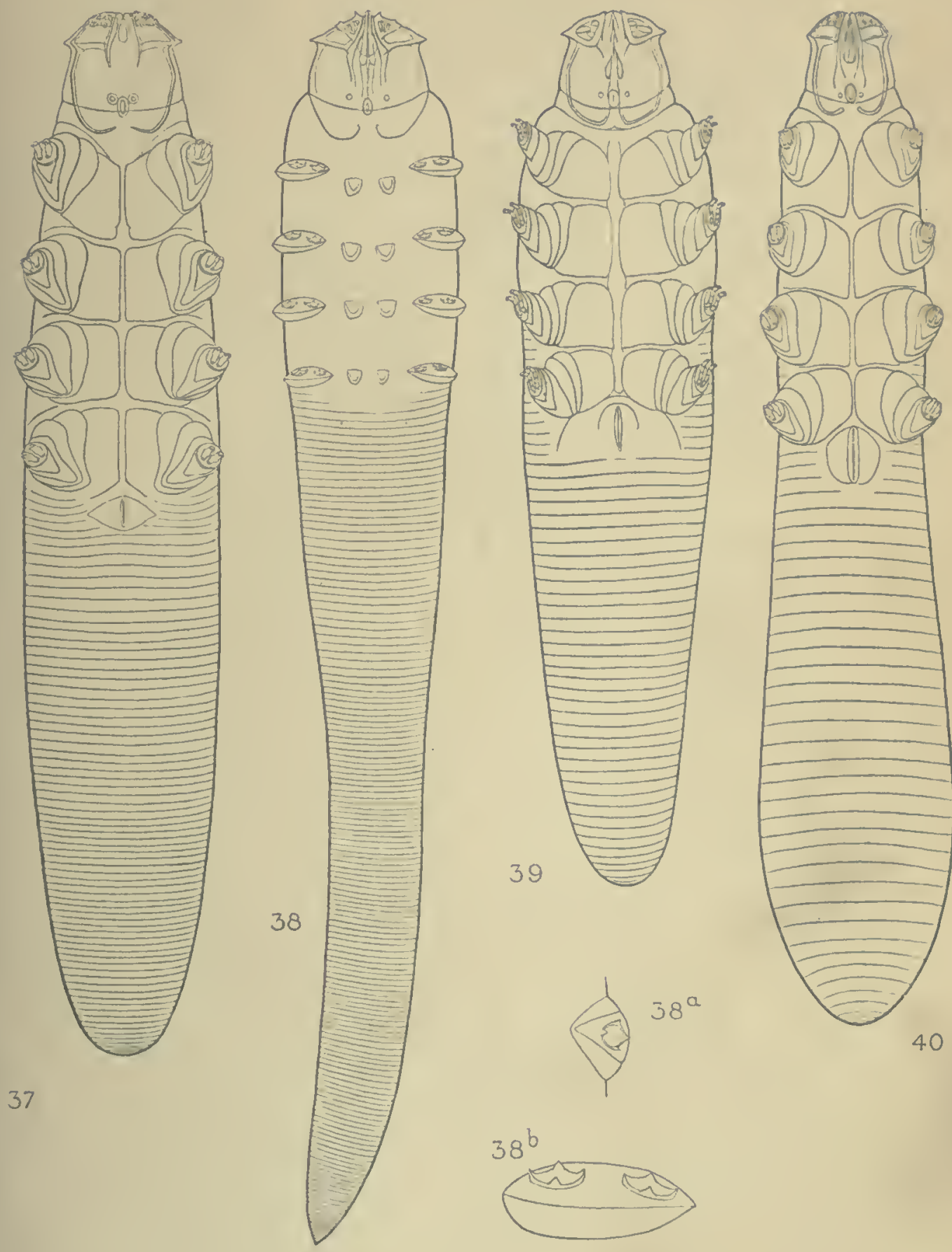

$38^{b}$ 



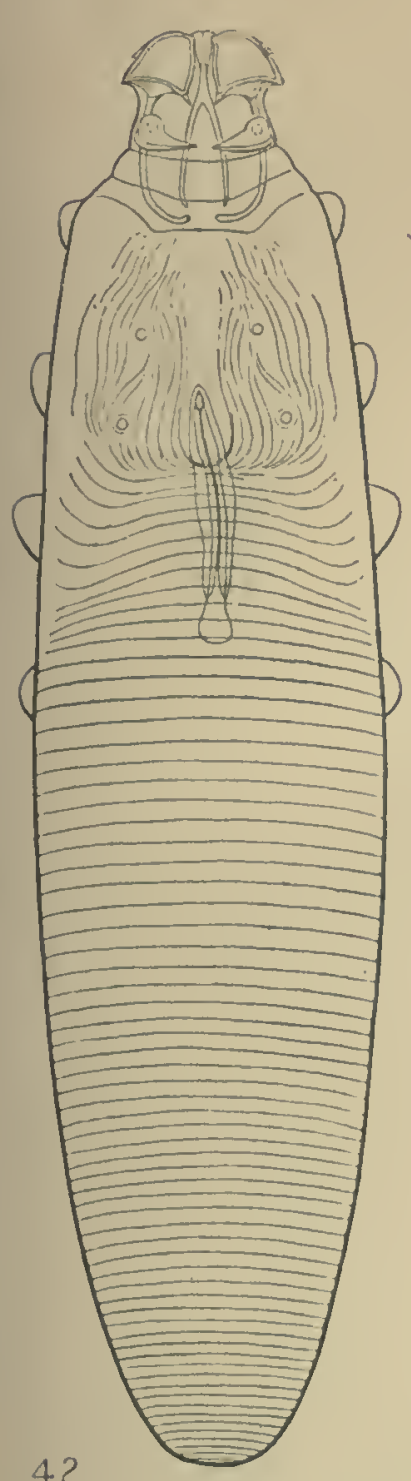

42

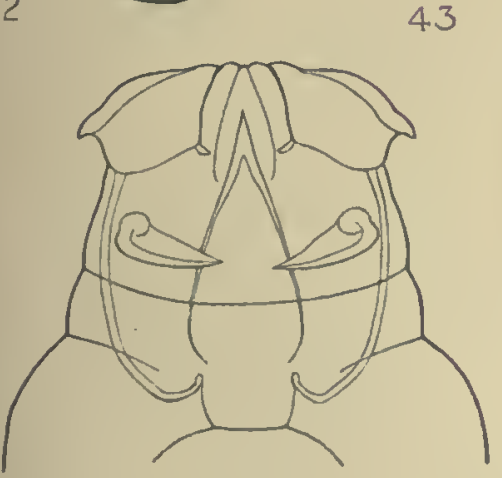

41
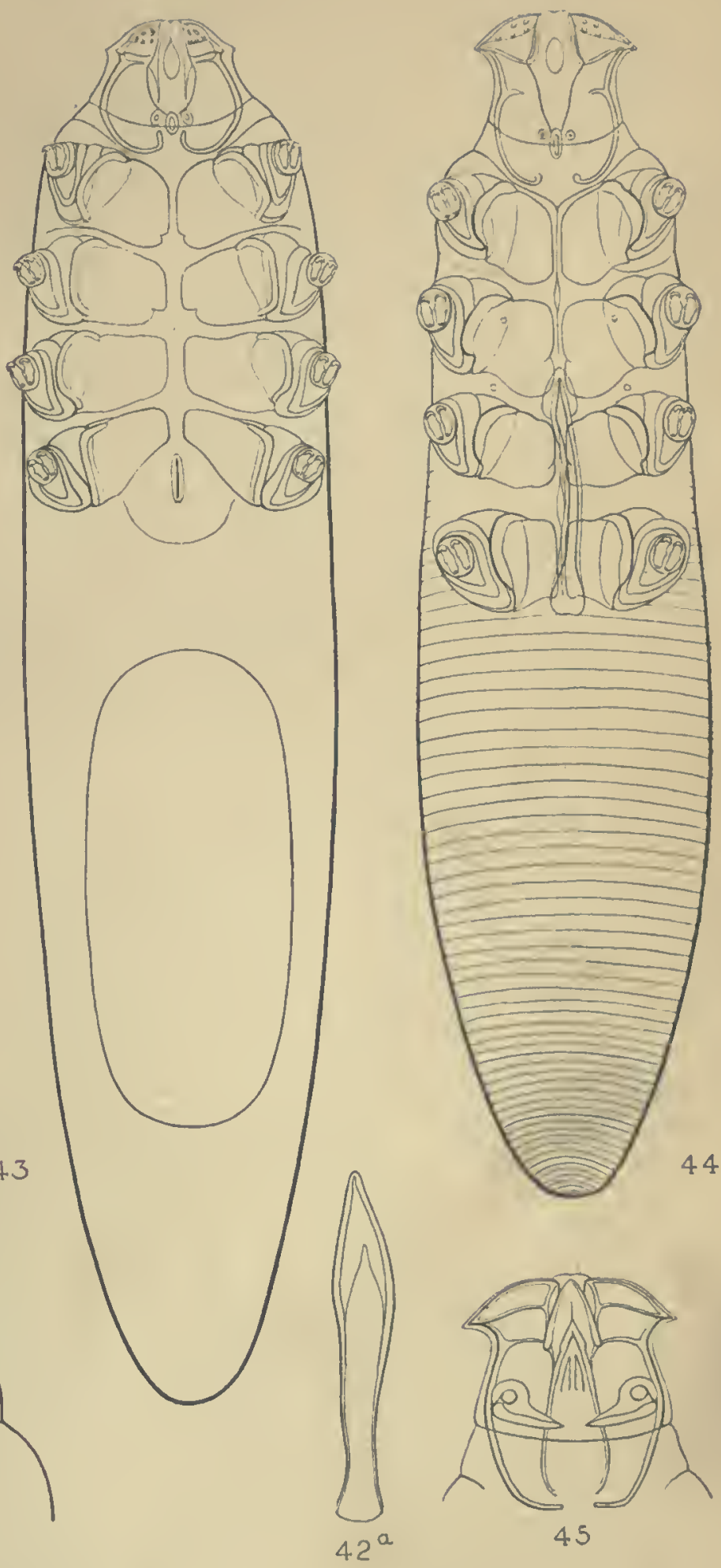



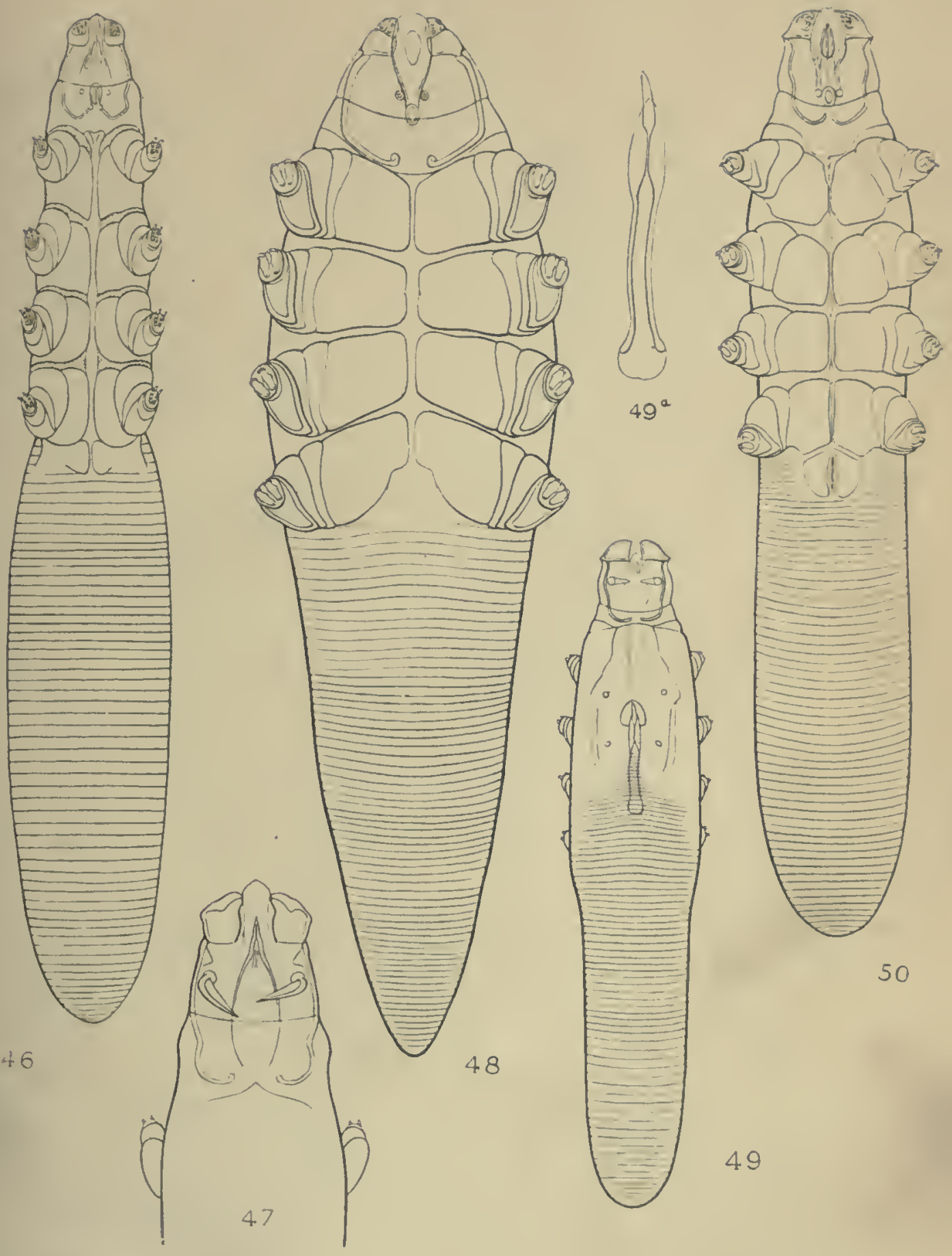




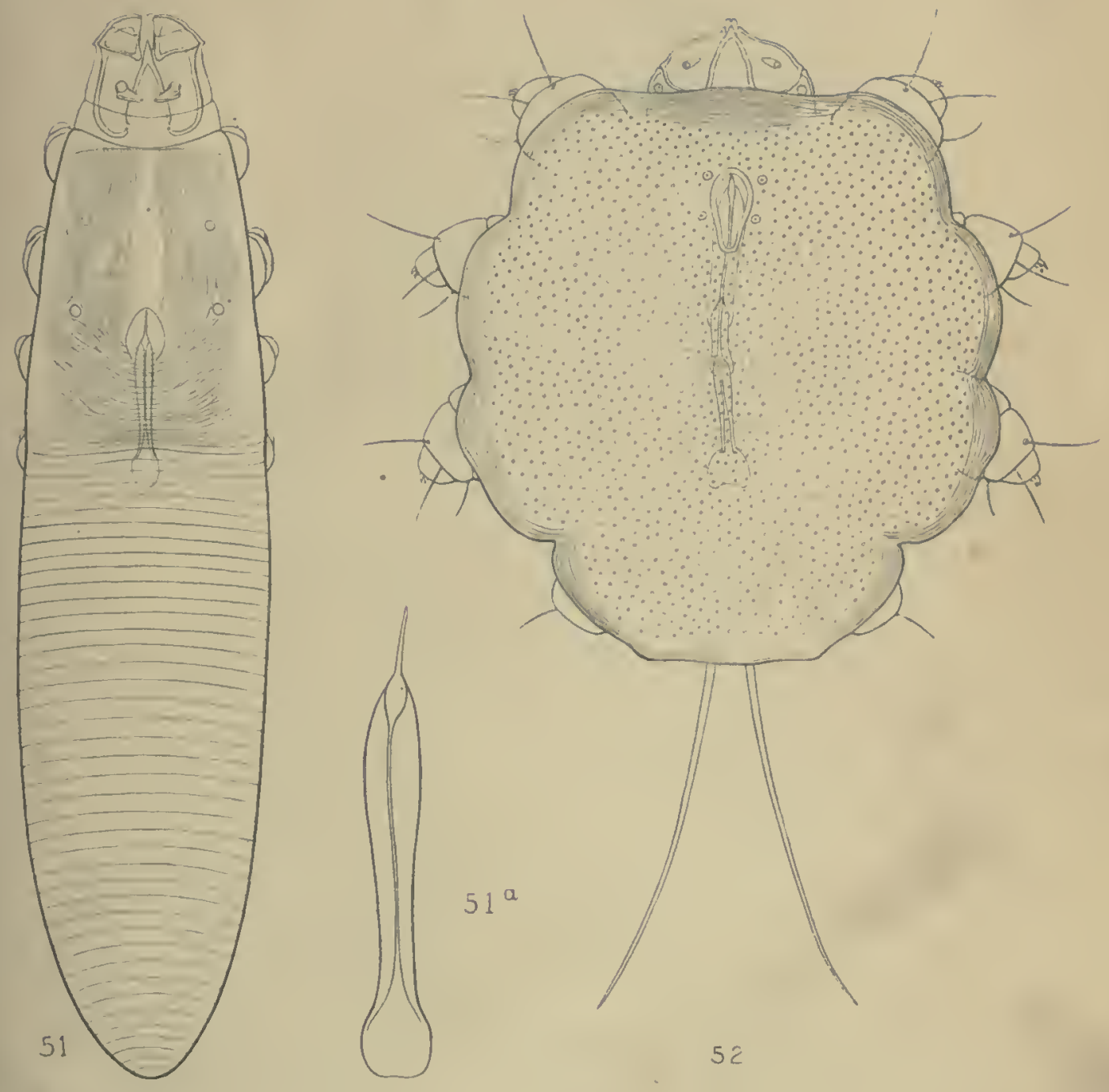



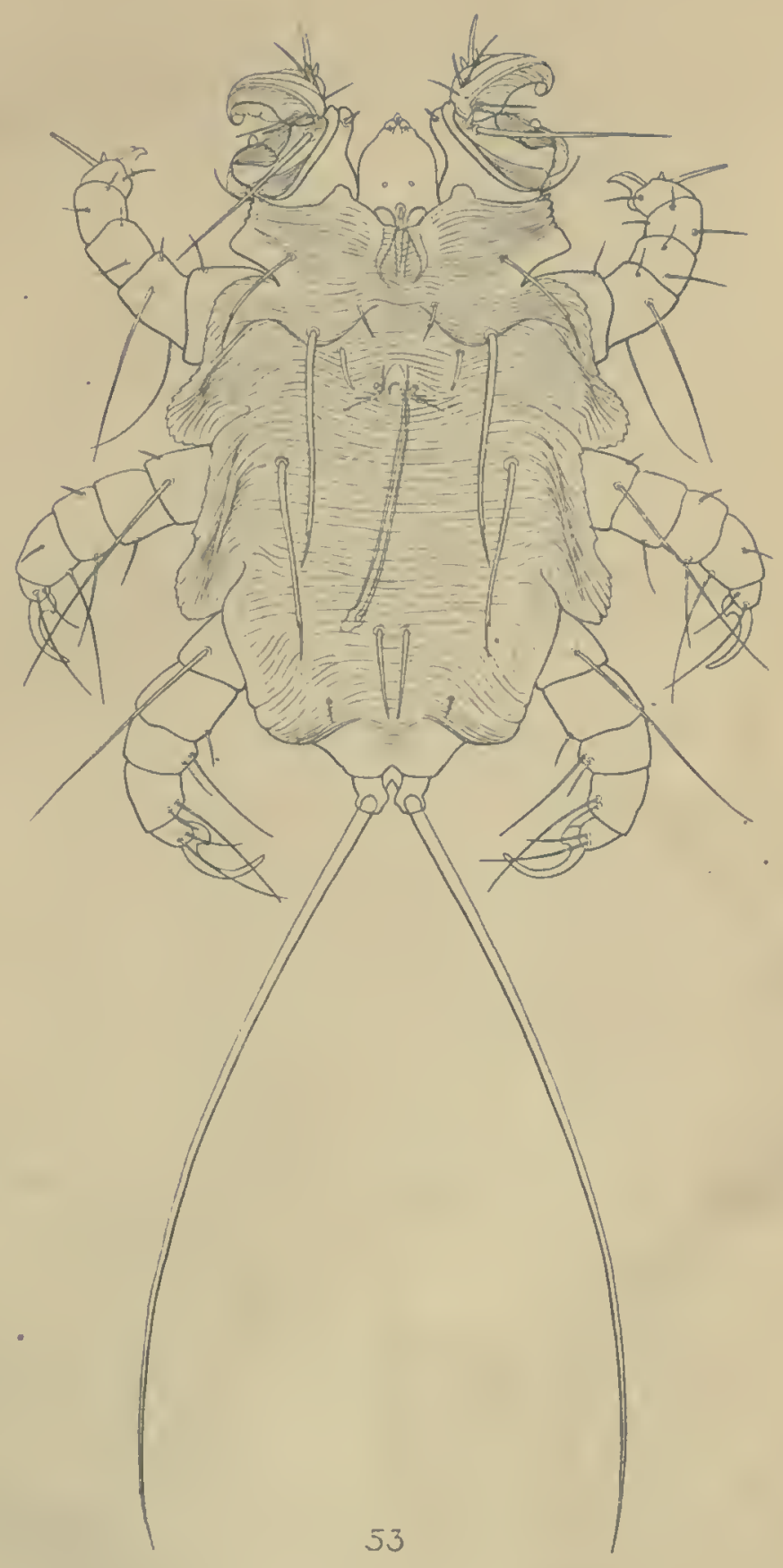




$$
641
$$




PLEASE DO NOT REMOVE CARDS OR SLIPS FROM THIS POCKET UNIVERSITY OF TORONTO LIBRARY 


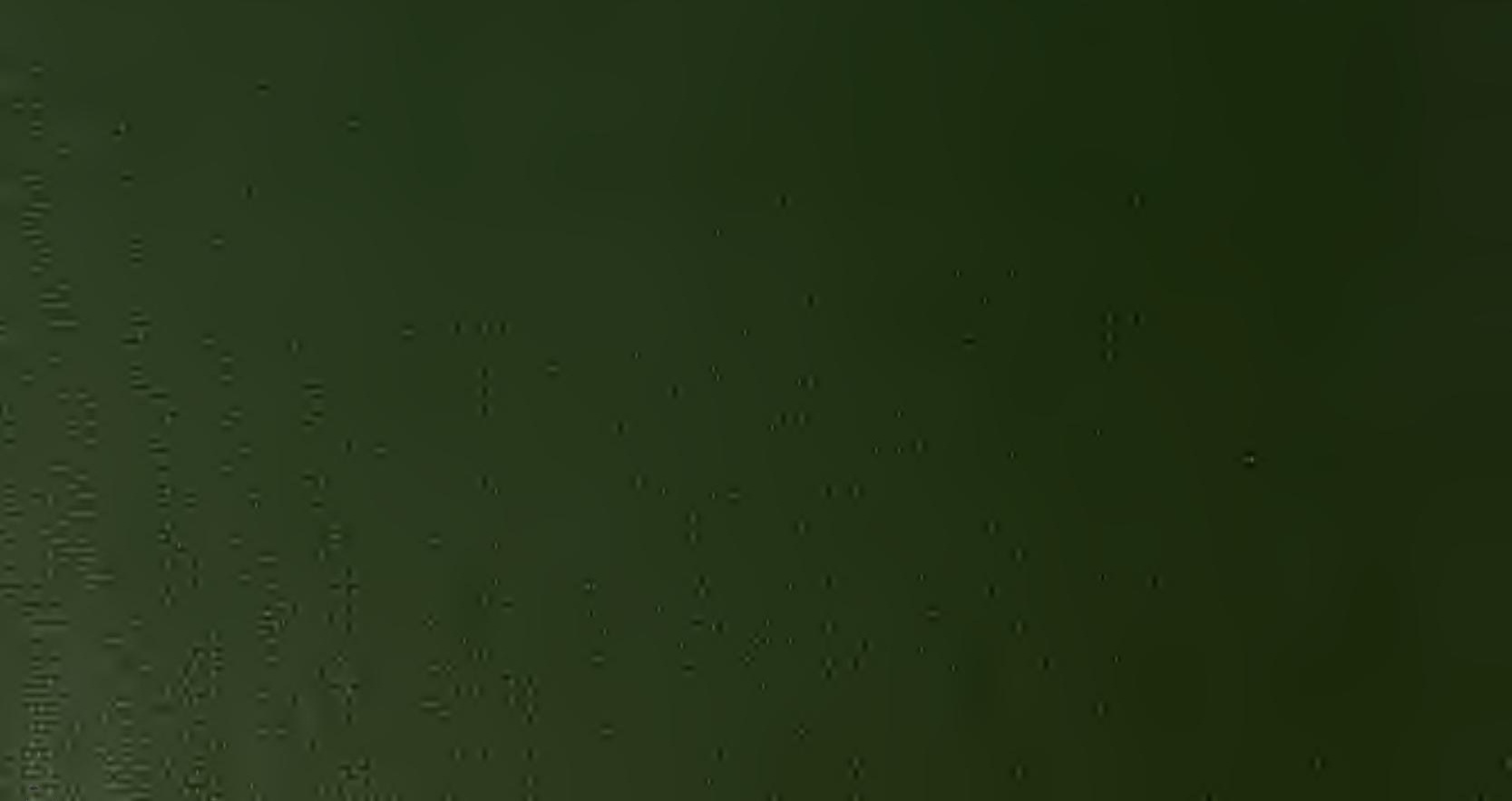

